\title{
Review \\ Multipurpose Agricultural Reuse of Microalgae Biomasses Employed for the Treatment of Urban Wastewater
}

\author{
Emanuele La Bella (D), Andrea Baglieri *(D), Ferdinando Fragalà and Ivana Puglisi
}

check for updates

Citation: La Bella, E.; Baglieri, A.; Fragalà, F.; Puglisi, I. Multipurpose Agricultural Reuse of Microalgae Biomasses Employed for the Treatment of Urban Wastewater. Agronomy 2022, 12, 234. https:// doi.org/10.3390/agronomy12020234 Academic Editor: Claudio Ciavatta Received: 23 December 2021 Accepted: 13 January 2022 Published: 18 January 2022

Publisher's Note: MDPI stays neutral with regard to jurisdictional claims in published maps and institutional affiliations.

Copyright: (C) 2022 by the authors. Licensee MDPI, Basel, Switzerland. This article is an open access article distributed under the terms and conditions of the Creative Commons Attribution (CC BY) license (https:// creativecommons.org/licenses/by/ $4.0 /$ )
Department of Agriculture, Food and Environment (Di3A), University of Catania, 95123 Catania, Italy; emanuele.labella@phd.unict.it (E.L.B.); ferdinando.fragala@phd.unict.it (F.F.); ipuglisi@unict.it (I.P.)

* Correspondence: abaglie@unict.it

Abstract: The pollution of water caused by the excessive presence of organic and inorganic compounds, such as nitrates, phosphates, heavy metals, antibiotics, agrochemicals, etc., is one of the major environmental problems in many countries. Various approaches to remediate wastewater are available, and this review mainly provides the state of the art about the possible adoption of microalgae-based treatments (phycoremediation), which may represent a good alternative to conventional purification methods. Because of its composition, wastewater can provide several nutritional compounds (e.g., carbon, nitrogen, and phosphorus), which represent the essential nutrients for microalgae growth. Microalgae are also attracting the interest of worldwide researchers due to their multipurpose applications; in particular, microalgae cells can represent a useful feedstock for various sectors, among these, the agricultural sector. This review proposes a detailed description of the possible application of microalgae in the process of remediation of wastewaters of different sources, highlighting their possible advantages. Moreover, the review aims to report the application of the microalgae biomasses and their extracts in agriculture, as microalgae-based products can represent a valid alternative to traditional agrochemicals, offering sustainable solutions to improve agricultural technologies. Therefore, since the recently developed wastewater depuration technology based on phycoremediation may directly provide valuable microalgae biomasses, it can be used as a powerful starting means to produce agricultural products able to improve yield and quality of crops (biostimulants, biofertilizers), as well as induce pest and disease resistance (biopesticides).

Keywords: wastewater; phycoremediation; microalgae; biostimulant; biofertilizer; biopesticide

\section{Introduction}

The pollution of agricultural, industrial, and municipal wastewaters with many organic and inorganic compounds, such as nitrates, phosphates, heavy metals, etc., is one of the most critical and common environmental problems in the main industrialized countries. The excessive presence of pollutants, particularly nitrogen and phosphorus, causes ecosystem problems and subsequent eutrophication of waterbodies, producing alteration of water system health [1].

Wastewater treatment is an important issue, and it globally cannot be managed by a single technology because of the extremely variable scales, depending on different types of contaminants, different wastewater sources, as well as different regional conditions which are involved [2]. Conventional wastewater treatment systems mainly focus on the elimination of solid suspension and the reduction of biological oxygen demand $\left(\mathrm{BOD}_{5}\right)$ by activated sludge [3].

Therefore, the presence of a wide range of pollutants, continuously discharged in urban wastewater, such as pharmaceutically active compounds, personal care products, pesticides, synthetic and natural hormones, and industrial chemicals, represents a serious problem to the environment and human health. These chemicals are also called contaminants of emerging concern (CECs) [4]. However, the capability of conventional methods in the 
elimination of microcompounds and inorganic nutrients is not always effective towards a complete removal. Moreover, the management of municipal wastewater through the conventional methods, such as tricking filters, activated sludge process, or oxidation ponds, is often very expensive. To solve these problems, good alternatives seem to be represented by new technologies, such as magnetic field and biological membrane reactors, especially in the local contexts [5,6]. The employ of the magnetic field is indicated for the remediation of urban wastewater, and it provides high efficiency in water treatment, especially in hardness, turbidity, and minerals removal [5]. The biological membrane reactors are based on pressure separation techniques and have many advantages over traditional methods, the most important of which are represented by very high phase separation efficiency, high quality of treated wastewater, and the possibility to remove specific pollutants [6]. In this contest, another new and sustainable biotechnology for wastewater treatment is represented by phycoremediation.

\section{Conventional Purification Methods of Wastewaters}

Conventional purification methods of wastewater involve a combination of physical, chemical, and biological processes, and operations to remove insoluble particles and soluble contaminants from effluents. There is not a single method capable of adequate treatment, mainly due to the complex nature of effluents [7].

The conventional wastewater treatments usually consist of five steps, described in Figure 1 [7]:

1. Preliminary treatment (physical and mechanical) includes screening, grinding, grit removal, flotation, equalization, and flocculation. The primary objective of this treatment consists of the removal of solids and other large substances often present in raw wastewater [8]. This step aims to remove or reduce, in size, the solids.

2. Primary treatment (physiochemical and chemical) involves the physical processes of screening, comminution, and sedimentation. This stage is aimed to remove solid substances, both organic and inorganic, from wastewater [9]. Some forms of organic nitrogen, organic phosphorous, and heavy metals associated with solids are also removed during this process [8].

3. Secondary treatment or purification (chemical and biological) is based on the use of microorganisms to remove the contaminants. Several aerobic biological processes are used in the way in which the oxygen is supplied to the microorganisms, and in the rate at which organisms metabolize the organic matter [8]. The main purpose of these treatments is the removal of fine suspended and dispersed solids, and dissolved organics.

4. Tertiary or final treatment (physical and chemical) is the final process that enhances the quality of wastewater before it is reused or discharged to the environment, and treatment of the sludge formed.

5. Treatment of the sludge (supervised tipping, recycling, incineration) consists of the sustainable management of the sludge in order to reduce the impact on the environment.

The number of stages adopted depends on the extent of pollutant removal and the mechanisms through which pollutants are removed [9]. 


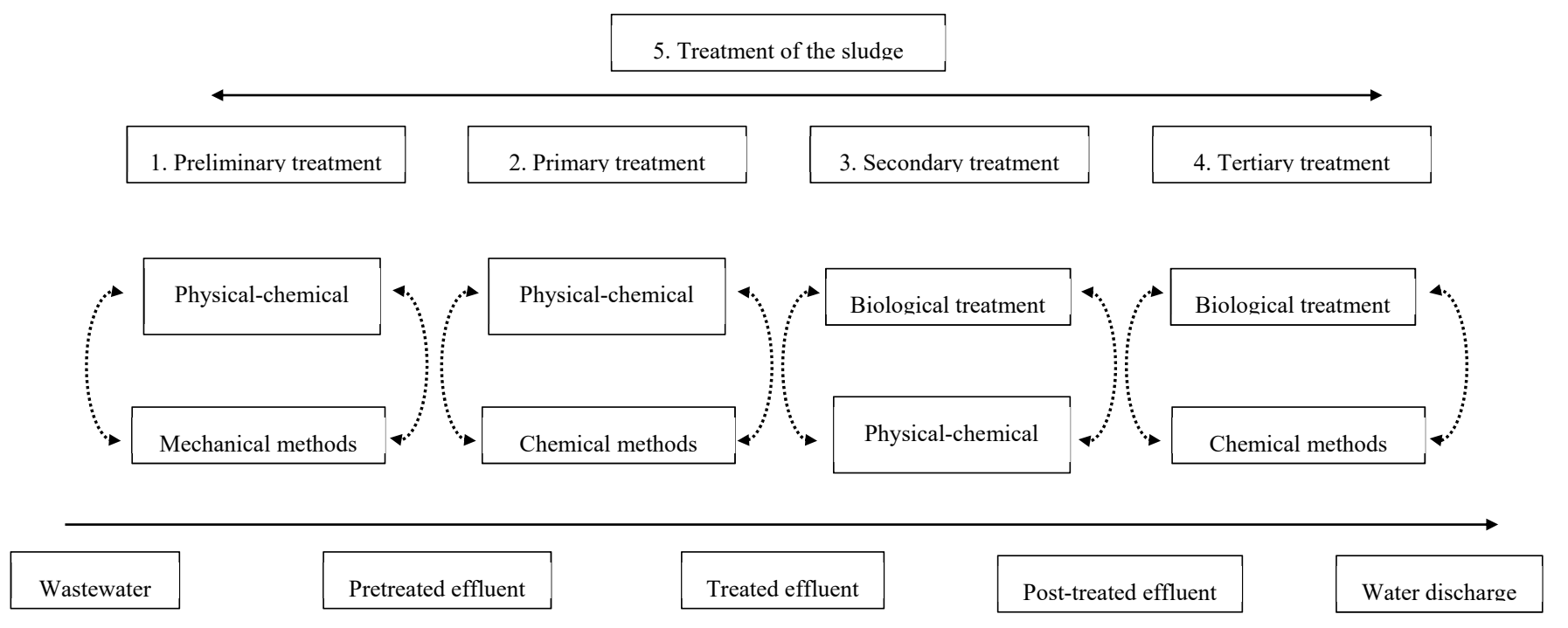

Figure 1. Main processes for the decontamination of wastewater (adapted by [7]).

\section{Phytoremediation}

An environmentally friendly and cost-effective technology for conventional treatments is represented by phytoremediation. Some plants are able to accumulate pollutants through their roots, and then translocate these compounds to the aboveground part of their body [10]. This method seems to be particularly indicated for the management of urban wastewater, containing a great variety of contaminants along with higher contents of biodegradable organic matter [11].

Phytoremediation is based on the application of vegetation and microorganisms for recovery of many pollutants and environmental decontamination. In this process, a crucial role is played by aquatic plants, which are able to absorb different compounds, such as organic and inorganic contaminants, heavy metals, and pharmaceutical pollutants present in agricultural, domestic, and industrial wastewaters.

Phytoremediation follows different mechanisms, such as phytoextraction, phytostabilization, phytovolatilization, and rhizofiltration [12].

The efficiency of the phytoremediation systems in the removal of different pollutants, such as nutrients, heavy metals, organic matter, agrochemicals, and polycyclic aromatic hydrocarbons, are reported in literature [13]. Physical, chemical, and biological processes, such as volatilization, sorption, sedimentation, photodegradation, plant uptake, and microbial degradation, may occur simultaneously, contributing to remove many types of compounds [14].

Table 1 reports the advantages and disadvantages of phytoremediation approaches in wastewater treatment [15].

Table 1. Advantages and disadvantages of phytoremediation of wastewater (adapted by [15]).

\begin{tabular}{cc}
\hline Advantages & Disadvantages \\
\hline Cheaper than conventional methods & Limited to shallow contaminants \\
Low energy requirement, solar driven & $\begin{array}{c}\text { Phytotoxicity of contaminants } \\
\text { High public acceptance }\end{array}$ \\
Use of natural and renewable source & Unknown effects of biodegradation products \\
Less secondary waste generation & Less carbon footprint \\
Reclamation of wastewater and nutrient recovery \\
Generation of feedstock for different applications \\
Possibility of harvesting the plants for the \\
extraction of absorbed and accumulated \\
contaminants such as toxic heavy metals for \\
recycling
\end{tabular}




\section{Phycoremediation}

The microalgae-based wastewater treatment process is one of the most promising technologies for the treatment and nutrient recovery of wastewaters from various sources (industrial, municipal, and agricultural): microalgae could be adapted to a variety of water bodies, can be extensively used to treat effluents [16], and could provide a tertiary biotreatment coupled with the production of potentially valuable biomass [17].

Therefore, this technology offers a good solution for their ability in the fixation of inorganic compounds, including carbon dioxide and heavy metals [18-21]. This method has two main aims: direct uptake of water contaminants (Figure 2), and the improvement of the purification performance of microalgae-bacteria aggregates by providing additional oxygen from photosynthesis (Figure 3), thus reducing the total energy costs of direct oxygen supply [22]. This advantage is made possible by the metabolic flexibility of microalgae, since they can be as follows:

- $\quad$ Autotrophic: microalgae grow by obtaining energy through the absorption of light energy for the reduction of $\mathrm{CO}_{2}$ by oxidation of the substrates with the release of $\mathrm{O}_{2}$.

- Heterotrophic: microalgae grow using organic carbon in the dark, solving problems related to the presence and distribution of light and $\mathrm{CO}_{2}$.

- Mixotrophic: microalgae grow depending on the environmental conditions in their regime, during which $\mathrm{CO}_{2}$ and organic carbon may be assimilated, depending on their availability, under either autotrophic or heterotrophic conditions.

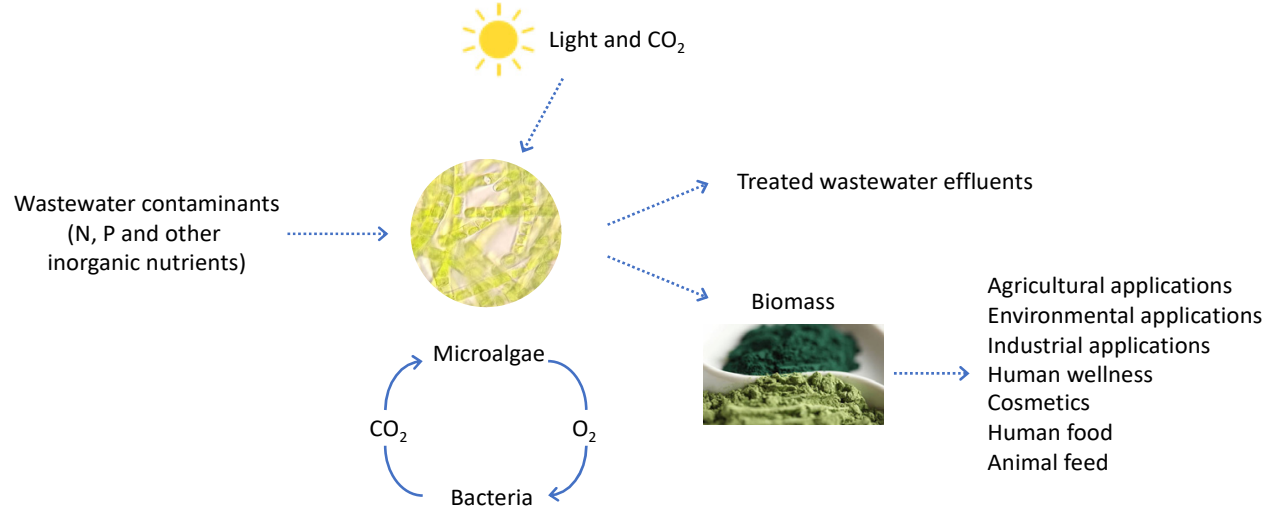

Figure 2. Uptake mechanism of nutrients and interactions among bacteria and microalgae.

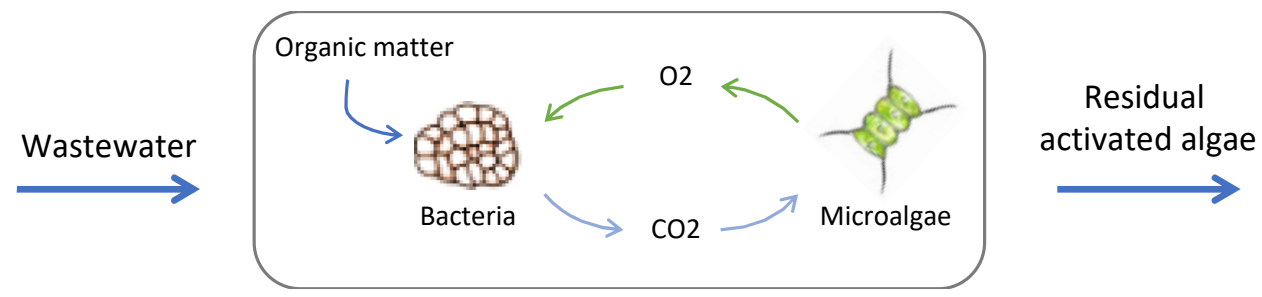

Figure 3. Aerobic treatment step.

In the actual context of a desirable circular and bio-based economy, microalgae treatment is considered an optimal option for its capability of treating wastewater in a single step. Meanwhile, the production of microalgae has also attracted the attention of researchers for their further multipurpose uses: in fact, they can be used to produce biochar, biofertilizers, biofuels, and biomaterials for the food and feed sectors [23].

Until now, the research on microalgae-based wastewater treatment has focused on the most common species, such as Chlorella sp., Ankistrodesmus sp., and Scenedesmus sp.; however, their efficiencies are different. The removal efficiency rates of pollutants in term of nitrate $\left(\mathrm{NO}_{3}{ }^{-}\right)$, nitrite $\left(\mathrm{NO}_{2}{ }^{-}\right)$, ammonium $\left(\mathrm{NH}_{4}{ }^{+}\right)$, total nitrogen $(\mathrm{N})$, phosphorus $(\mathrm{P})$, 
biochemical oxygen demand $\left(\mathrm{BOD}_{5}\right)$, and chemical oxygen demand (COD) in wastewaters of different sources treated with microalgae are reported in Table 2.

Table 2. Removal rates by microalgae of pollutants in wastewaters of different sources.

\begin{tabular}{|c|c|c|c|}
\hline $\begin{array}{l}\text { Microalgae } \\
\text { Species }\end{array}$ & Wastewater Type & $\begin{array}{c}\text { Treatment } \\
\text { Efficiency (\%) }\end{array}$ & Reference \\
\hline Anabaena flos-aquae & $\begin{array}{l}\text { Ammonium form nitrogen } \\
\text { group }\end{array}$ & $\begin{array}{l}\text { N: } 94.9 \\
\text { P: } 96.8\end{array}$ & [24] \\
\hline Anabaena flos-aquae & $\begin{array}{l}\text { Orthophosphate form } \\
\text { phosphorous group }\end{array}$ & P: 97.7 & [24] \\
\hline $\begin{array}{l}\text { Ankistrodesmus } \\
\quad \text { falcatus }\end{array}$ & Aquaculture wastewater & $\begin{array}{c}\mathrm{NO}_{3-}: 80.85 \\
\mathrm{NO}_{2^{-}}: 99.73 \\
\mathrm{NH}_{4^{+}}: 86.45 \\
\text { P: } 98.52 \\
\text { COD: } 61\end{array}$ & [15] \\
\hline Arthrospira platensis & Dairy farm wastewater & $\begin{array}{c}\mathrm{NO}_{3} \mathrm{~N}: 99.6 \\
\mathrm{NH}_{4}-\mathrm{N}: ~ 100 \\
\mathrm{PO}_{4}-\mathrm{P}: 98.8 \\
\mathrm{COD}: 98.4\end{array}$ & [25] \\
\hline Calothrix sp. & Sewage water & $\begin{array}{l}\text { N: } 57 \\
P: 74\end{array}$ & [26] \\
\hline $\begin{array}{l}\text { Chlamydomonas sp. } \\
\text { (YG04) }\end{array}$ & Municipal wastewater & $\begin{array}{l}\text { N: } 77.57 \\
\text { P: } 100\end{array}$ & [27] \\
\hline $\begin{array}{l}\text { Chlamydomonas sp. } \\
\text { (YG05) }\end{array}$ & Municipal wastewater & $\begin{array}{l}\mathrm{N}: 74.49 \\
\mathrm{P}: 100\end{array}$ & {$[27]$} \\
\hline Chlorella sp. & Domestic wastewater & $\begin{array}{c}\text { N: } 50.2 \\
\text { P: } 85.7 \\
\text { BOD }_{5}: 68.4 \\
\text { COD: } 67.2\end{array}$ & [28] \\
\hline Chlorella sp. & $\begin{array}{l}\text { Municipal wastewater before } \\
\text { primary settling }\end{array}$ & $\begin{array}{c}\mathrm{NH}_{4}-\mathrm{N}: 82.4 \\
\text { P: } 83.2 \\
\text { COD: } 50.9\end{array}$ & [29] \\
\hline Chlorella sp. & $\begin{array}{l}\text { Municipal wastewater after } \\
\text { primary settling }\end{array}$ & $\begin{array}{c}\mathrm{NH}_{4}-\mathrm{N}: 74.7 \\
\text { P: } 90.6 \\
\text { COD: } 56.5\end{array}$ & [29] \\
\hline Chlorella sp. & $\begin{array}{l}\text { Municipal wastewater after } \\
\text { activated sludge tank }\end{array}$ & $\begin{array}{l}\mathrm{NH}_{4}-\mathrm{N}: 62.5 \\
\mathrm{P}: 4.7\end{array}$ & [29] \\
\hline Chlorella sp. & $\begin{array}{l}\text { Municipal wastewater } \\
\text { generated in sludge centrifuge }\end{array}$ & $\begin{array}{c}\mathrm{NH}_{4}-\mathrm{N}: 78.3 \\
\text { P: } 85.6 \\
\text { COD: } 83\end{array}$ & [29] \\
\hline Chlorella sp. & Sewage water & $\begin{array}{l}\text { N: } 78 \\
\text { P: } 45\end{array}$ & [26] \\
\hline Chlorella sp. (YG01) & Municipal wastewater & $\begin{array}{l}\text { N: } 84.11 \\
P: 82.36\end{array}$ & [27] \\
\hline Chlorella sp. (YG02) & Municipal wastewater & $\begin{array}{l}\mathrm{N}: 68.23 \\
\mathrm{P}: 99\end{array}$ & [27] \\
\hline Chlorella vulgaris & $\begin{array}{c}\text { Wastewater from the Shatin } \\
\text { sewage treat. }\end{array}$ & $\begin{array}{l}\text { N: } 86 \\
\text { P: } 78\end{array}$ & [30] \\
\hline
\end{tabular}


Table 2. Cont.

\begin{tabular}{|c|c|c|c|}
\hline $\begin{array}{l}\text { Microalgae } \\
\text { Species }\end{array}$ & Wastewater Type & $\begin{array}{c}\text { Treatment } \\
\text { Efficiency }(\%)\end{array}$ & Reference \\
\hline Chlorella vulgaris & Agricultural wastewater & $\begin{array}{c}\mathrm{NH}_{4}-\mathrm{N}: 99 \\
\mathrm{NO}_{3}-\mathrm{N}: 83 \\
\text { P: } 88\end{array}$ & {$[31]$} \\
\hline Lyngbya sp. & Sewage water & $\begin{array}{l}\text { N: } 59 \\
P: 92\end{array}$ & [26] \\
\hline Oocystis sp. (YG03) & Municipal wastewater & $\begin{array}{l}\mathrm{N}: 83.32 \\
\mathrm{P}: 99.01\end{array}$ & [27] \\
\hline Scenedesmus obliquus & $\begin{array}{l}\text { Secondary effluent-without } \\
\text { stirring }\left(20^{\circ} \mathrm{C}\right)\end{array}$ & $\begin{array}{l}\text { N: } 94 \\
P: 97\end{array}$ & [32] \\
\hline Scenedesmus obliquus & $\begin{array}{l}\text { Secondary effluent-without } \\
\text { stirring }\left(25^{\circ} \mathrm{C}\right)\end{array}$ & $\begin{array}{l}\text { N: } 99 \\
P: 98\end{array}$ & [32] \\
\hline Scenedesmus obliquus & $\begin{array}{l}\text { Secondary effluent-without } \\
\text { stirring }\left(30^{\circ} \mathrm{C}\right)\end{array}$ & $\begin{array}{l}\text { N: } 99 \\
P: 94\end{array}$ & {$[32]$} \\
\hline Scenedesmus obliquus & $\begin{array}{l}\text { Secondary effluent-without } \\
\text { stirring }\left(35^{\circ} \mathrm{C}\right)\end{array}$ & $\begin{array}{l}\text { N: } 79 \\
P: 54\end{array}$ & {$[32]$} \\
\hline Scenedesmus obliquus & $\begin{array}{l}\text { Secondary effluent-with } \\
\text { stirring }\left(20^{\circ} \mathrm{C}\right)\end{array}$ & $\begin{array}{l}\text { N: } 80 \\
P: 98\end{array}$ & [32] \\
\hline Scenedesmus obliquus & $\begin{array}{l}\text { Secondary effluent-with } \\
\text { stirring }\left(25^{\circ} \mathrm{C}\right)\end{array}$ & $\begin{array}{l}\text { N: } 100 \\
P: 98\end{array}$ & {$[32]$} \\
\hline Scenedesmus obliquus & $\begin{array}{l}\text { Secondary effluent-with } \\
\text { stirring }\left(30^{\circ} \mathrm{C}\right)\end{array}$ & $\begin{array}{l}\text { N: } 99 \\
\text { P: } 97\end{array}$ & [32] \\
\hline Scenedesmus obliquus & $\begin{array}{l}\text { Secondary effluent-with } \\
\text { stirring }\left(35^{\circ} \mathrm{C}\right)\end{array}$ & $\begin{array}{l}\text { N: } 82 \\
\text { P: } 62\end{array}$ & [32] \\
\hline $\begin{array}{l}\text { Scenedesmus } \\
\text { quadricauda }\end{array}$ & Agricultural wastewater & $\begin{array}{c}\mathrm{NH}_{4}-\mathrm{N}: 99 \\
\mathrm{NO}_{3}-\mathrm{N}: 5 \\
\mathrm{P}: 94\end{array}$ & [31] \\
\hline Scenedesmus sp. LX1 & Secondary effluent & $\begin{array}{l}\text { N: } 98 \\
\text { P: } 98\end{array}$ & [33] \\
\hline Ulothrix sp. & Sewage water & $\begin{array}{l}\text { N: } 67 \\
\text { P: } 85\end{array}$ & [26] \\
\hline
\end{tabular}

\subsection{Chlorella sp.}

Chlorella sp. is widely used for wastewater treatment, and has proven abilities of removing nitrogen, phosphorus, and COD, mixing with bacteria or not, which show their potentiality as tertiary biotreatment step (Figure 2) [29]. Microalgae of the genus Chlorella can be grown both in autotrophic and mixotrophic cultivation conditions, reaching high growth rates.

Lau et al. [30] reported that Chlorella vulgaris can reduce $86 \%$ of the inorganic nitrogen and $78 \%$ of the inorganic phosphates in primary settled wastewater. Instead, Colak and Kaya [28] reported that Chlorella sp. can remove $50.2 \%$ and $85.7 \%$ of these two elements from industrial wastewater.

Wang et al. [29] evaluated the ability of Chlorella sp. to remove nitrogen, phosphorus, $\mathrm{COD}$, and metals on wastewaters sampled from four different points of the treatment process flow of a local municipal wastewater treatment plant: wastewater before primary settling, wastewater after primary settling, wastewater after activated sludge tank, and wastewater generated in sludge centrifuge. The results, reported in Table 2, demonstrate the efficiency in nutrient removal of Chlorella sp.

Baglieri et al. [34] tested the ability of $C$. vulgaris to remove contaminants from agricultural wastewater, considering two case studies: (i) the first on the growth rate of the species 
in wastewater from a hydroponic greenhouse cultivation, in order to evaluate the degree of removal of the main inorganic compounds; (ii) the second on microalgae ability to degrade five different active ingredients commonly used in agricultural practices (pyrimethanil, metalaxyl, iprodione, fenhexamid, and triclopyr). C. vulgaris demonstrated a good aptitude for the decontamination, removing about $99 \%$ of nitric nitrogen, $83 \%$ of the ammonia nitrogen, and $88 \%$ of phosphates. A reduction in the contents of other elements, such as iron, potassium, and total organic carbon, was also observed. The microalgae also showed ability to grow in the presence of all five active ingredients used in the trials, although in some cases, signals of suffering from a slightly toxic effect were observed. The dissipation of metalaxyl and fenhexamid provided the most interesting results, occurring faster in the presence of microalgae [34]. With regard to iprodione and triclopyr, the dissipation was less evident. Pyrimethanil showed a different behavior with respect to the other pesticides, resulting in more resistance to dissipation, although in the presence of C. vulgaris [34].

Rasoul-Amini et al. [27] tested two strains of Chlorella sp. (YG01 and YG02) for removal of nitrogen and phosphorus from municipal wastewater. The experiment confirmed that Chlorella sp. (YG01) can be considered an efficient nutrient remover in wastewaters of different origin, while in the other strains, a minor efficiency in the purification process was shown. All this evidence is summarized in Table 2.

\subsection{Ankistrodesmus sp.}

Ankistrodesmus sp. is a green phototrophic microalgae that has a long crescent shape with a slight curve at both ends [35]. Mixotrophic conditions of growth of Ankistrodesmus sp. have shown the highest specific growth.

The phycoremediation ability of Ankistrodesmus sp. is reported only in a few studies available in literature. Among these, Ahmad Ansari et al. [15] focused on the potential strains, biomass-enhancement strategy, nutrient removal potential, and biochemical composition of the microalgae. In this study, Ankistrodesmus falcatus was grown using aquaculture wastewater. With regard to the removal efficiency, $A$. falcatus showed good performance (e.g., $80.85 \%$ of $\mathrm{NO}_{3}{ }^{-}, 98.52 \%$ of $\mathrm{P}$, and $61 \%$ of COD), and the results are reported in detail in Table 2.

Also available in literature are some studies on the possible use of Ankistrodesmus sp. as an autoflocculating microalgae with a shape, and zeta potential that could have the ability to coagulate other microalgae species, as Chlorella sp., and so act as bioflocculant in harvesting biomass [35].

\subsection{Scenedesmus sp.}

Scenedesmus sp. is one of the microalgae genera particularly interesting for wastewater treatment due to its efficiency of nutrient removal, rapid growth rate, and high biomass productivity $[32,36,37]$. Scenedesmus sp. can be grown under autotrophic, heterotrophic, and mixotrophic cultivation conditions.

Xin et al. [33] studied the properties of lipid accumulation and nutrient removal of Scenedesmus sp. LX1 in secondary effluent. With regard to the total nitrogen and total phosphorus contents, the results showed a notable removal efficiency, for both nutrients, of over $98 \%$ (Table 2).

Martinez et al. [32] studied the kinetics of $\mathrm{N}$ and $\mathrm{P}$ elimination as well as simultaneous growth of $S$. obliquus in the effluent from a secondary-sewage-treatment facility, under different conditions of stirring and temperature. The researchers chose as experimental conditions $20,25,30$, and $35^{\circ} \mathrm{C}$, representing the range of average temperatures of wastewater in different seasons of a warm climate, and two levels of mixing: maximum (magnetic stirring and air bubbling in the culture medium) and minimum (absence of magnetic stirring), as reported in Table 2.

Many works are also available in literature about the cultivation process of microalgae to promote the degradation of inorganic compounds and pesticides in water. Baglieri et al. [31], as above reported on C. vulgaris in the same case studies, also evaluated 
the Scenedesmus quadricauda removal efficiency, showing in the wastewater of hydroponic greenhouse cultivation a consumption of about $99 \%$ nitric nitrogen, but only $5 \%$ of the ammonia nitrogen, and a remotion of $94 \%$ phosphates. S. quadricauda also showed to be able to grow in the presence of all five active ingredients (pyrimethanil, metalaxyl, iprodione, fenhexamid, and triclopyr) used in the trials, determining a reduction in their contents, and providing similar results to those above reported for C. vulgaris [31]. Another study in which the removal ability of active ingredients from agricultural wastewater by microalgae was evaluated was conducted by Kurade et al. [38]. The researchers screened S. obliquus for the removal of diazinon, an organophosphorus insecticide. The removal efficiency was

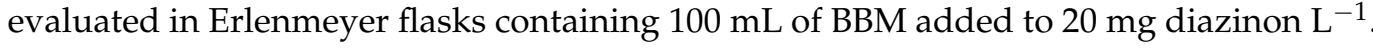
However, S. obliquus did not show high removal capacity of diazinon.

Although microalgae-based wastewater treatment is oriented towards efficient removal of nitrogen and phosphorus, not all contaminants can be eradicated [1].

\subsection{Other Species}

In literature, other studies about microalgae species and cyanobacteria able to remove organic and inorganic compounds from wastewaters, of different origins, are reported. Rasoul-Amini et al. [27] evaluated the removal efficiency of nitrogen and phosphorus from municipal wastewater of the following species: two strains of Chlamydomonas sp. (YG04 and YG05), and one strain of Oocystis sp. (YG03). The results showed that Chlamydomonas sp. (YG04 and YG05) can act as efficient nutrient removers from wastewaters of different origin, while Oocystis sp. (YG03) showed a minor efficiency in the purification process, as reported in Table 2.

Zhu et al. [24] studied the nitrogen and phosphorus removal during the Anabaena flos-aquae biofilm growth, in two nutrient mediums, containing different nitrogen and phosphorus compounds. The results demonstrated that the nitrogen and phosphorus removal reached 94.9 and $96.8 \%$, respectively, in the form of ammonium nitrogen, while $97.7 \%$ of phosphorus were removed in the form of orthophosphate phosphorous (Table 2).

Renuka et al. [26] tested the phycoremediation ability of four microalgae strains: Calothrix sp., Lyngbya sp., Chlorella sp., and Ulothrix sp. The researchers observed a different behavior of the strains, obtaining in all the cases a significant removal of $\mathrm{NO}_{3}-\mathrm{N}$ (ranging from $57-78 \%$ ) and $\mathrm{PO}_{4}-\mathrm{P}(44-91 \%)$, as reported in detail in Table 2.

Hena et al. [25] evaluated the removal ability of Arthrospira platensis cultivated in dairy farm wastewater for biodiesel production. The results showed a good aptitude of $A$. platensis to remove the main pollutants.

\section{Employ of Microalgae in Agriculture}

In the last decades, the increase in worldwide population has caused an additional demand for food supplies, which may be obtained through an improvement of agricultural productivity. At the same time, the development of eco-friendly alternative methods of production to reduce the use of chemicals in agriculture appears necessary for the attenuation of their environmental effects [39,40]. In this context, a lot of attention has been focused on the development of bio-based products, among them microalgae products, to improve plant growth, yield, and quality by enhancing plant nutrition, and reducing abiotic and biotic stresses impacts [41-43].

However, until now, the use of microalgae for applications in agriculture is an undergoing initiation, and the production of microalgae is only an emerging activity, due to its potential economic and commercial opportunities, but shows high costs of cultivation $[44,45]$. An interesting solution to increase the cost-effectiveness of this process may be represented by the application of low-cost resources, such as nutrient-rich wastewaters and agricultural byproducts $[31,45,46]$.

To this aim, Barone et al. [47] proposed the cocultivation of tomato plants and microalgae (C. vulgaris and S. quadricauda) in a hydroponic system, in which a biostimulant effect of agro-industrial waste both on tomato and microalgae (C. vulgaris and S. quadricauda) 
was proved [48]. Even Zhang et al. [49] suggested the simultaneous cultivation of Chlorella infusionum and tomato plants by using a hydroponic system, with the input only for crop production. These cultivation systems may represent a good opportunity to both reduce the costs for microalgae cultivation and provide a benefit for plant growth.

Microalgae and cyanobacteria represent an important source of biologically active compounds, such as hormone-like substances, proteins, and polysaccharides, known for their benefits as antioxidant agents, plant-growth promotors, etc. These biological compounds may improve the agricultural productivity by different modes of action: soils' improvement, crops' protection, and direct plant growth stimulation [50].

Considering these roles, microalgae-based products used in agriculture could be classified into three major categories: biostimulants, biofertilizers, and biopesticides.

Biostimulants, usually applied as extracts, may improve crops' productivity by acting directly on the plant, enhancing plant's metabolism, and thus plant's growth [50]. These products can exert stimulatory activity under both optimal and adverse conditions, improving plant resistance and tolerance against stress conditions [51,52].

Biofertilizers are biologically-based compounds that promote an improvement in crops' yields through their activity at the soil level, providing macro- and micronutrients for plant growth [52-55]. Typically, these products are applied as biomass.

Biopesticides are known for their activity against pests and plant pathogens [50]. These compounds have antimicrobial, antioxidant, antiviral, or antifungal properties and promote crops' development by protecting plants from pathogenic organisms. However, agronomic, physiological, chemical, biochemical, and molecular studies are required to better understand the changes induced by the microalgal products in crop productions.

\subsection{Biostimulants}

Plant biostimulants, according to the European Union regulation (2019/1009), are "products able to stimulate plant nutrition processes independently of the product's nutrient content with the sole aim of improving one or more of the following characteristics of the plant or the plant rhizosphere: nutrient use efficiency; tolerance to abiotic stress; quality traits; availability of confined nutrients in soil or rhizosphere". In other words, biostimulants can be defined as products able to promote the growth and quality of food crops, vegetables, and fruits when applied in small quantities to the soil or on the foliar surface directly. They may positively affect plant growth by enhancing water uptake, root and shoot growth, tolerance to abiotic stress, protein content in plant tissues, and the activity of several enzymes [56-60]. However, from a legislative point of view, the inclusion of biostimulants in fertilizer legislation has always presented a series of disputes, which, until now, have not been completely clear.

Plant biostimulants include a wide range of natural substances, such as humic acids, protein hydrolysates, seaweed extracts, and beneficial microorganisms, such as mycorrhizal fungi and plant growth-promoting rhizobacteria [61]. According to Colla et al. [62] and Battacharyya et al. [63], protein hydrolysates, along with macroalgae seaweed extracts, may be considered natural plant biostimulants. However, an emerging class of compounds, able to stimulate primary and secondary metabolism in plants, is represented by microalgae products. Indeed, different studies have demonstrated the biostimulant effects both of microalgae biomasses and their extracts.

Microalgae biomasses were shown to contain micro- and macronutrients, particularly $\mathrm{N}, \mathrm{P}$, and $\mathrm{K}$, and different plant growth-promoting substances, such as auxins, cytokinins, betaines, etc. [64-66].

Ronga et al. [52] reported that the main species of microalgae showing biostimulant effects that are commercially available are Scenedesmus spp., Chlorella spp., Acutodesmus spp., Isochrysis spp., Chaetoceros spp., Arthrospira spp., and Dunaliella spp.

Barone et al. [67] showed that different concentrations of extracts from microalgae C. vulgaris or $S$. quadricauda may act as biostimulant in the early stages of sugar beet cultivation by improving root and plant growth, by modulating gene expression related to 
the nutrient acquisition in sugar beet. Moreover, the effects of C. vulgaris and S. quadricauda microalgae extracts showed that their application, especially the one of $C$. vulgaris, improves the germination rates of Beta vulgaris seeds cv. Shannon and root development, promoting further nutrient acquisition and plant growth [68]. Furthermore, Barone et al. [69] evaluated the response of soil enzymatic activities to the application of living cells of $C$. vulgaris and S. quadricauda and their extracts. The authors, in order to evaluate the biostimulant effects of the microalgae, monitored the main enzymatic activities of the soils: fluorescein diacetate hydrolysis, dehydrogenases, acid and alkaline phosphomonoesterase, and urease activities. The microalgal extracts were added to the soil at two different concentrations, 0.5 and $1 \mathrm{mg}$ of dry organic matter of the extracts per $\mathrm{kg}$ of soil $(\mathrm{w} / \mathrm{w})$; while the living cells of $C$. vulgaris and $S$. quadricauda were added to the soil corresponding to the amount necessary to obtain an extract concentration of $1.5 \mathrm{mg} \operatorname{Corg} \mathrm{L}^{-1}$. The results showed that both the microalgae and their extracts positively affected soil biological activity by increasing values of the biochemical index of potential soil fertility.

Puglisi et al. [70] investigated the potential use of a S. quadricauda extract as a biostimulant on lettuce seedlings, grown on pumice substrate. The researchers carried out two radical treatments, using a concentration of the microalgal extract corresponding to $1 \mathrm{mg}$ Corg $\mathrm{L}^{-1}$, and evaluated the physiological parameters, chlorophyll, carotenoid, and total protein contents, as well as several plant enzymatic activities involved in primary and secondary metabolisms. The results showed that the $S$. quadricauda extract positively affected the growth of lettuce seedlings, mainly acting at the shoot level, determining an increase in dry matter, chlorophylls, carotenoids, proteins, and enhancing the activities of several activities (glutamate synthase-GOGAT; glutamine synthase-GS; citrate synthase-CS; malate dehydrogenase-MDH; phenylalanine ammonia lyase-PAL).

La Bella et al. [71] studied the effects of the foliar application of a C. vulgaris extract in lettuce plants, monitoring the morphobiometric parameters, chlorophylls, carotenoids, total protein contents, and several enzymatic activities involved in different biosynthetic pathways. The researchers performed three foliar applications of the microalgal extract, using a concentration of $1 \mathrm{mg}$ Corg $\mathrm{L}^{-1}$, one week apart. The results showed that the C. vulgaris extract positively influenced the growth of lettuce seedlings, increasing all the parameters tested, and from a biochemical point of view, primary and secondary metabolisms of shoots, in particular nitrogen metabolism, were positively influenced.

Puglisi et al. [72] investigated the effects of two different methods of application of a C. vulgaris extract, foliar spray and root drenching, on lettuce seedlings, monitoring their morphobiometric parameters and chlorophyll, carotenoid, and total protein contents. The authors also tested several enzymatic activities involved in primary and secondary metabolisms. In this study two consecutive applications, 1 week apart, of the microalgal extract $\left(1 \mathrm{mg}\right.$ Corg $\left.\mathrm{L}^{-1}\right)$ were performed, and the samples at different times $(1,4$, and 7 days after the first treatment and at 7 days after the second treatment) were collected. The results demonstrated that both application methods positively affected the growth of lettuce seedlings, increasing the dry matter, chlorophyll, carotenoid, and protein contents in the edible portion of the plant. From a biochemical point of view, the extract application methods influenced the primary and secondary metabolism by coordinated regulation of $C$ and $\mathrm{N}$ metabolic pathways, which may represent the key point in the mechanism of action.

Garcia-Gonzalez and Sommerfeld [73] evaluated biostimulant properties of the microalga Acutodesmus dimorphus on Roma tomato plants. The researchers tested the influence of the cellular extracts, at different concentrations, growth medium, and culture of $A$. dimorphus on the seed germination. They also evaluated the effects of foliar spray applications of the aqueous extracts, applied in various concentrations. The results showed a positive influence of all treatments on the seed germination: germination energy calculations demonstrated a relationship between increasing extract concentrations and increasing germination energy. The most interesting result regarding germination energy, an increase of $40 \%$ compared with the untreated control, was obtained with the extract applied at $100 \%$ concentration; while the fastest germination speed at $63 \%$ was observed on seeds 
treated with $A$. dimorphus living culture. With regard to foliar applications, all treatments positively influenced plant growth, leading also to greater flowering. However, foliar spray application at higher concentrations showed a smaller increase in the development of the plants, compared to the other treatments.

Plaza et al. [74] studied the effects of foliar spray applications with extracts of Scenedesmus almeriensis and A. platensis hydrolysates on Petunia x hybrida plant development and leaf nutrients status. The researchers performed three treatments: foliar application with water; foliar application with $A$. platensis $\left(10 \mathrm{~g} \mathrm{~L}^{-1}\right.$ of biomass); foliar application with $S$. almeriensis (10 $\mathrm{g} \mathrm{L}^{-1}$ of biomass). The treatments were applied five times. The results of these trials demonstrated positive influences of both microalgae extracts. With regard to biometric parameters, the application of Arthrospira and Scenedesmus increased root dry weight and flower dry and fresh weight compared with the control. The results also showed that microalgae hydrolysate extracts supply can improve the plant nutrition status, particularly for $\mathrm{P}, \mathrm{K}, \mathrm{Ca}$, and $\mathrm{Mg}$.

Mutale-joan et al. [75] investigated the effects of 18 crude bio-extracts (CBEs), obtained by acid hydrolysis, from microalgae and cyanobacteria on tomato plants (Solanum lycopersicum L.) at three different biomass concentrations: $0.1,0.5$, and $1 \mathrm{~g} \mathrm{~L}^{-1}$ under laboratory conditions. The evaluated species were: Aphanothese sp., Arthrospira maxima, A. platensis, Chlorella pyrenoidosa, C. vulgaris, Chlorella ellipsoidae, C. sorokiniana, Chlorella marina, Scenedesmus dimorphus, S. obliquus, Chlamydomonas reinhardtii, Dunaliella salina, Tetraselmis marina, Tetraselmis sp., Tetraselmis suecica, Porphyridium sp., Isochrysis galbana and Nannochloropsis gaditana. The results showed that the application of CBEs to tomato plants improved chlorophyll contents, nutrient uptake, and, in many cases, the root and shoot length and dry weight.

Specifically, Aphanothese sp. extracts enhanced root length $(112.6 \%)$, root $(34.8 \%)$, and shoot $(58.7 \%)$ dry weights. The enhanced root lengths also improved nutrient uptake from the soil. With regard to the pigments contents, the maximum increase in chlorophyll b content $(92.5 \%, 92.3 \%$, and $83.9 \%)$ across all treatments were observed with Aphanothece sp., A. maxima, and C. pyrenoidosa extracts for freshwater species, respectively, and Tetraselmis sp. and N. gaditana extracts for seawater species, which increased by $93.3 \%$ and $83.9 \%$, respectively, compared with control plants. In this study, the researchers also highlighted the potential of CBEs on many metabolic pathways.

Table 3 reported the microalgae species retrieved from recent literature, used as living cells or extracts, showing a plant biostimulant effect.

Table 3. Biostimulant effects of different microalgae species.

\begin{tabular}{|c|c|c|c|c|}
\hline $\begin{array}{c}\text { Microalgae } \\
\text { Species }\end{array}$ & Extract/Biomass & Application & Effects & Reference \\
\hline A. dimorphus & $\begin{array}{l}\text { Cellular extracts, } \\
\text { growth medium } \\
\text { and culture }\end{array}$ & $\begin{array}{c}\text { Solanum } \\
\text { lycopersicum cv } \\
\text { Roma }\end{array}$ & $\begin{array}{l}\text { Improving seed } \\
\text { germination. } \\
\text { Increasing plant } \\
\text { growth through } \\
\text { foliar application }\end{array}$ & {$[73]$} \\
\hline A. maxima & $\begin{array}{c}\text { Crude } \\
\text { Bio-Extracts } \\
\text { (CBEs) }\end{array}$ & $\begin{array}{c}\text { Solanum } \\
\text { lycopersicum }\end{array}$ & $\begin{array}{l}\text { Improving } \\
\text { chlorophyll contents, } \\
\text { nutrient uptake, root } \\
\text { and shoot length } \\
\text { and dry weight }\end{array}$ & {$[75]$} \\
\hline
\end{tabular}


Table 3. Cont.

\begin{tabular}{|c|c|c|c|c|}
\hline $\begin{array}{c}\text { Microalgae } \\
\text { Species }\end{array}$ & Extract/Biomass & Application & Effects & Reference \\
\hline A. platensis & $\begin{array}{l}\text { Hydrolysate } \\
\text { extracts }\end{array}$ & Petunia $x$ hybrida & $\begin{array}{l}\text { Increasing root dry } \\
\text { weight, flower dry } \\
\text { weight and fresh } \\
\text { weight. Improving } \\
\text { plant nutrition } \\
\text { status }\end{array}$ & [74] \\
\hline A. platensis & $\begin{array}{l}\text { Crude } \\
\text { Bio-Extracts } \\
\text { (CBEs) }\end{array}$ & $\begin{array}{c}\text { Solanum } \\
\text { lycopersicum }\end{array}$ & $\begin{array}{l}\text { Improving } \\
\text { chlorophyll contents, } \\
\text { nutrient uptake, root } \\
\text { and shoot length } \\
\text { and dry weight }\end{array}$ & [75] \\
\hline Aphanothese sp. & $\begin{array}{l}\text { Crude } \\
\text { Bio-Extracts } \\
\text { (CBEs) }\end{array}$ & $\begin{array}{c}\text { Solanum } \\
\text { lycopersicum }\end{array}$ & $\begin{array}{l}\text { Improving } \\
\text { chlorophyll contents, } \\
\text { nutrient uptake, root } \\
\text { and shoot length } \\
\text { and dry weight }\end{array}$ & [75] \\
\hline C. ellipsoidae & $\begin{array}{l}\text { Crude } \\
\text { Bio-Extracts } \\
\text { (CBEs) }\end{array}$ & $\begin{array}{c}\text { Solanum } \\
\text { lycopersicum }\end{array}$ & $\begin{array}{l}\text { Improving } \\
\text { chlorophyll contents, } \\
\text { nutrient uptake, root } \\
\text { and shoot length } \\
\text { and dry weight }\end{array}$ & [75] \\
\hline C. marina & $\begin{array}{l}\text { Crude } \\
\text { Bio-Extracts } \\
\text { (CBEs) }\end{array}$ & $\begin{array}{c}\text { Solanum } \\
\text { lycopersicum }\end{array}$ & $\begin{array}{l}\text { Improving } \\
\text { chlorophyll contents, } \\
\text { nutrient uptake, root } \\
\text { and shoot length } \\
\text { and dry weight }\end{array}$ & [75] \\
\hline C. pyrenoidosa & $\begin{array}{l}\text { Crude } \\
\text { Bio-Extracts } \\
\text { (CBEs) }\end{array}$ & $\begin{array}{c}\text { Solanum } \\
\text { lycopersicum }\end{array}$ & $\begin{array}{l}\text { Improving } \\
\text { chlorophyll contents, } \\
\text { nutrient uptake, root } \\
\text { and shoot length } \\
\text { and dry weight }\end{array}$ & [75] \\
\hline C. reinhardtii & $\begin{array}{l}\text { Crude } \\
\text { Bio-Extracts } \\
\text { (CBEs) }\end{array}$ & $\begin{array}{c}\text { Solanum } \\
\text { lycopersicum }\end{array}$ & $\begin{array}{l}\text { Improving } \\
\text { chlorophyll contents, } \\
\text { nutrient uptake, root } \\
\text { and shoot length } \\
\text { and dry weight }\end{array}$ & [75] \\
\hline C. sorokiniana & $\begin{array}{l}\text { Crude } \\
\text { Bio-Extracts } \\
\text { (CBEs) }\end{array}$ & $\begin{array}{c}\text { Solanum } \\
\text { lycopersicum }\end{array}$ & $\begin{array}{l}\text { Improving } \\
\text { chlorophyll contents, } \\
\text { nutrient uptake, root } \\
\text { and shoot length } \\
\text { and dry weight }\end{array}$ & [75] \\
\hline C. vulgaris & Cellular extracts & $\begin{array}{c}\text { Beta vulgaris cv } \\
\text { Shannon }\end{array}$ & $\begin{array}{c}\text { Improving } \\
\text { germination rates } \\
\text { and root } \\
\text { development }\end{array}$ & {$[68]$} \\
\hline C. vulgaris & Cellular extracts & $\begin{array}{c}\text { Lettuce } \\
\text { seedlings }\end{array}$ & $\begin{array}{l}\text { Increasing dry } \\
\text { matter, chlorophylls, } \\
\text { carotenoids, } \\
\text { proteins, and } \\
\text { influencing the } \\
\text { activities of several } \\
\text { enzymes }\end{array}$ & {$[71]$} \\
\hline
\end{tabular}


Table 3. Cont.

\begin{tabular}{|c|c|c|c|c|}
\hline $\begin{array}{c}\text { Microalgae } \\
\text { Species }\end{array}$ & Extract/Biomass & Application & Effects & Reference \\
\hline C. vulgaris & Cellular extracts & $\begin{array}{c}\text { Lettuce } \\
\text { seedlings }\end{array}$ & $\begin{array}{l}\text { Increasing dry } \\
\text { matter, chlorophylls, } \\
\text { carotenoids, } \\
\text { proteins, and } \\
\text { influencing the } \\
\text { activities of several } \\
\text { enzymes }\end{array}$ & [72] \\
\hline C. vulgaris & $\begin{array}{l}\text { Cellular extracts } \\
\text { and living cells }\end{array}$ & $\begin{array}{l}\text { Application on } \\
\text { soil }\end{array}$ & $\begin{array}{l}\text { Increasing values of } \\
\text { the biochemical } \\
\text { index of potential } \\
\text { soil fertility }\end{array}$ & [69] \\
\hline C. vulgaris & $\begin{array}{l}\text { Crude } \\
\text { Bio-Extracts } \\
\text { (CBEs) }\end{array}$ & $\begin{array}{c}\text { Solanum } \\
\text { lycopersicum }\end{array}$ & $\begin{array}{l}\text { Improving } \\
\text { chlorophyll contents, } \\
\text { nutrient uptake, root } \\
\text { and shoot length } \\
\text { and dry weight }\end{array}$ & [75] \\
\hline D. salina & $\begin{array}{l}\text { Crude } \\
\text { Bio-Extracts } \\
\text { (CBEs) }\end{array}$ & $\begin{array}{c}\text { Solanum } \\
\text { lycopersicum }\end{array}$ & $\begin{array}{l}\text { Improving } \\
\text { chlorophyll contents, } \\
\text { nutrient uptake, root } \\
\text { and shoot length } \\
\text { and dry weight }\end{array}$ & [75] \\
\hline I. galbana & $\begin{array}{l}\text { Crude } \\
\text { Bio-Extracts } \\
\text { (CBEs) }\end{array}$ & $\begin{array}{c}\text { Solanum } \\
\text { lycopersicum }\end{array}$ & $\begin{array}{l}\text { Improving } \\
\text { chlorophyll contents, } \\
\text { nutrient uptake, root } \\
\text { and shoot length } \\
\text { and dry weight }\end{array}$ & [75] \\
\hline N. gaditana & $\begin{array}{l}\text { Crude } \\
\text { Bio-Extracts } \\
\text { (CBEs) }\end{array}$ & $\begin{array}{c}\text { Solanum } \\
\text { lycopersicum }\end{array}$ & $\begin{array}{l}\text { Improving } \\
\text { chlorophyll contents, } \\
\text { nutrient uptake, root } \\
\text { and shoot length } \\
\text { and dry weight }\end{array}$ & [75] \\
\hline Porphyridium sp. & $\begin{array}{l}\text { Crude } \\
\text { Bio-Extracts } \\
\text { (CBEs) }\end{array}$ & $\begin{array}{c}\text { Solanum } \\
\text { lycopersicum }\end{array}$ & $\begin{array}{l}\text { Improving } \\
\text { chlorophyll contents, } \\
\text { nutrient uptake, root } \\
\text { and shoot length } \\
\text { and dry weight }\end{array}$ & [75] \\
\hline S. almeriensis & $\begin{array}{l}\text { Hydrolysate } \\
\text { extracts }\end{array}$ & Petunia $x$ hybrida & $\begin{array}{l}\text { Increasing root dry } \\
\text { weight, flower dry } \\
\text { weight and fresh } \\
\text { weight. Improving } \\
\text { plant nutrition } \\
\text { status }\end{array}$ & [74] \\
\hline S. dimorphus & $\begin{array}{l}\text { Crude } \\
\text { Bio-Extracts } \\
\text { (CBEs) }\end{array}$ & $\begin{array}{c}\text { Solanum } \\
\text { lycopersicum }\end{array}$ & $\begin{array}{l}\text { Improving } \\
\text { chlorophyll contents, } \\
\text { nutrient uptake, root } \\
\text { and shoot length } \\
\text { and dry weight }\end{array}$ & [75] \\
\hline S. obliquus & $\begin{array}{l}\text { Crude } \\
\text { Bio-Extracts } \\
\text { (CBEs) }\end{array}$ & $\begin{array}{c}\text { Solanum } \\
\text { lycopersicum }\end{array}$ & $\begin{array}{c}\text { Improving } \\
\text { chlorophyll contents, } \\
\text { nutrient uptake, root } \\
\text { and shoot length } \\
\text { and dry weight }\end{array}$ & [75] \\
\hline
\end{tabular}


Table 3. Cont.

\begin{tabular}{|c|c|c|c|c|}
\hline $\begin{array}{l}\text { Microalgae } \\
\text { Species }\end{array}$ & Extract/Biomass & Application & Effects & Reference \\
\hline S. quadricauda & Cellular extracts & $\begin{array}{c}\text { Beta vulgaris cv } \\
\text { Shannon }\end{array}$ & $\begin{array}{c}\text { Improving } \\
\text { germination rates } \\
\text { and root } \\
\text { development }\end{array}$ & [68] \\
\hline S. quadricauda & $\begin{array}{l}\text { Cellular extracts } \\
\text { and living cells }\end{array}$ & $\begin{array}{c}\text { Application on } \\
\text { soil }\end{array}$ & $\begin{array}{l}\text { Increasing values of } \\
\text { the biochemical } \\
\text { index of potential } \\
\text { soil fertility }\end{array}$ & [69] \\
\hline S. quadricauda & Cellular extracts & $\begin{array}{c}\text { Lettuce } \\
\text { seedlings }\end{array}$ & $\begin{array}{l}\text { Increasing dry } \\
\text { matter, chlorophylls, } \\
\text { carotenoids, } \\
\text { proteins, and } \\
\text { influencing the } \\
\text { activities of several } \\
\text { enzymes }\end{array}$ & [70] \\
\hline T. marina & $\begin{array}{l}\text { Crude } \\
\text { Bio-Extracts } \\
\text { (CBEs) }\end{array}$ & $\begin{array}{c}\text { Solanum } \\
\text { lycopersicum }\end{array}$ & $\begin{array}{c}\text { Improving } \\
\text { chlorophyll contents, } \\
\text { nutrient uptake, root } \\
\text { and shoot length } \\
\text { and dry weight }\end{array}$ & [75] \\
\hline T. suecica & $\begin{array}{l}\text { Crude } \\
\text { Bio-Extracts } \\
\text { (CBEs) }\end{array}$ & $\begin{array}{c}\text { Solanum } \\
\text { lycopersicum }\end{array}$ & $\begin{array}{l}\text { Improving } \\
\text { chlorophyll contents, } \\
\text { nutrient uptake, root } \\
\text { and shoot length } \\
\text { and dry weight }\end{array}$ & [75] \\
\hline Tetraselmis sp. & $\begin{array}{l}\text { Crude } \\
\text { Bio-Extracts } \\
\text { (CBEs) }\end{array}$ & $\begin{array}{c}\text { Solanum } \\
\text { lycopersicum }\end{array}$ & $\begin{array}{l}\text { Improving } \\
\text { chlorophyll contents, } \\
\text { nutrient uptake, root } \\
\text { and shoot length } \\
\text { and dry weight }\end{array}$ & [75] \\
\hline
\end{tabular}

\subsection{Biofertilizers}

Fertilization is one of the most common agricultural practices used in order to obtain good crop yields. However, the massive use of synthetic fertilizers may cause serious environmental problems [76].

The European Parliament has recently launched a new regulation (EU—2019/1009) which defines the "fertilizing product" as "a substance, mixture, microorganism, or any other material, applied or intended to be applied on plants or their rhizosphere or on mushrooms or their mycosphere, or intended to constitute the rhizosphere or mycosphere, either on its own or mixed with another material, for the purpose of providing the plants or mushrooms with nutrient or improving their nutrition efficiency"; therefore the biofertilizers may be defined as products containing living or dormant microorganisms alone or in combination, which help in fixing atmospheric nitrogen or solubilizers soil nutrients in addition to the secretion of growth promoting substances for enhancing crop growth and yield [77].

In this regard, a valid option as biofertilizer may be represented by microalgae, with the potential function to prevent nutrient losses through a gradual release of nitrogen, phosphorous, and potassium [78,79].

However, microalgal products are considered borderline, showing intermediate effects between biostimulants and fertilizers [52]. 
Some studies, available in literature, highlight an association among greater nutrient uptake, higher biomass accumulation, and greater crop yields when microalgae are used as biofertilizers [80,81].

Wuang et al. [82] assessed the applicability of the biomass of Spirulina platensis as agricultural fertilizer to leafy vegetables (Eruca sativa, Amaranthus gangeticus, B. rapa ssp. chinensis, and Brassica oleracea alboglabra). The results showed the ability of Spirulinabased biofertilizers to enhance plant growth, influencing many biometric parameters and improving the germination process.

Elhafiz et al. [83] evaluated the effects of the microalgae C. vulgaris and C. pyrenoidosa on vegetable crops (lettuce, rice, eggplant, and cucumber) in salt-affected soil. For each crop, the authors tested the influence of both microalgal species on seed germination in Petri dishes, and only C. pyrenoidosa as biofertilizer for plotted plants. The microalgae were not applied as biomass, but as solution. The results highlighted the possible use of C. pyrenoidosa live cells as biofertilizer to promote the growth of vegetable crops in salt soil; indeed, the treated seedlings of the four crops had a positive effect from the biofertilizer, and had a major content of chlorophylls and were healthy.

Dineshkumar et al. [77] analyzed rice growth at different concentrations of microalgae C. vulgaris and S. platensis and determined their potentiality as biofertilizer application in order to have maximum yield. Both microalgal biomasses positively influenced the main growth parameters of the plants, allowing a reduction of $\mathrm{N}$ fertilizer up to 50 or $75 \%$ of the recommended dose. The authors also analyzed the seed yield characters of the rice plants, the biological activity, and chemical properties of soil. With regard to the seed yield characters, data obtained showed significant improvements in rice yield parameters. With regard to the biological activity and chemical properties of the soil, the application of microalgae enhanced dehydrogenase activity and nitrogenase, reduced soil $\mathrm{pH}$ and electric conductivity, and increased the availability of macronutrients in soil.

Another interesting example of microalgae soil application is reported for tomato. Coppens et al. [78] evaluated the potentiality of two types of microalgal biomass, microalgal bacterial flocs, dominated by filamentous microalgae Ulothrix sp. and Klebsormidium sp. from a raceway pond treating aquaculture wastewater, and a marine culture of Nannochloropsis sp. as organic slow-release fertilizers for tomato cultivation. The authors assessed the growth rate of the tomato plants and the tomato yield for each fertilizer treatment, as well as the composition of the leaves and the fruits. The results showed both microalgal fertilizers improved the fruit quality through an increase in sugar and carotenoid content, although a lower tomato yield was obtained. In Table 4 are summarized the microalgae species retrieved from recent literature, used as living cells or extracts, showing a biofertilizer effect.

Table 4. Biofertilizer effects of different microalgae species.

\begin{tabular}{|c|c|c|c|c|}
\hline $\begin{array}{c}\text { Microalgae } \\
\text { Species }\end{array}$ & Biomass/Solution & Application On & Effects & Reference \\
\hline C. pyrenoidosa & Solution & $\begin{array}{c}\text { Lactuca sativa } \\
\text { (lettuce) }\end{array}$ & $\begin{array}{c}\text { Improving } \\
\text { germination process } \\
\text { and salinity } \\
\text { tolerance, and } \\
\text { enhancing } \\
\text { chlorophyll content }\end{array}$ & [83] \\
\hline C. pyrenoidosa & Solution & Oryza sp. (rice) & $\begin{array}{l}\text { Improving } \\
\text { germination process } \\
\text { and salinity } \\
\text { tolerance, and } \\
\text { enhancing } \\
\text { chlorophyll content }\end{array}$ & [83] \\
\hline
\end{tabular}


Table 4. Cont.

\begin{tabular}{|c|c|c|c|c|}
\hline $\begin{array}{c}\text { Microalgae } \\
\text { Species }\end{array}$ & Biomass/Solution & Application On & Effects & Reference \\
\hline C. pyrenoidosa & Solution & $\begin{array}{l}\text { Solanum } \\
\text { melongena } \\
\text { (eggplant) }\end{array}$ & $\begin{array}{l}\text { Improving } \\
\text { germination process } \\
\text { and salinity } \\
\text { tolerance, and } \\
\text { enhancing } \\
\text { chlorophyll content }\end{array}$ & [83] \\
\hline C. pyrenoidosa & Solution & $\begin{array}{l}\text { Cucumis sativus } \\
\text { (cucumber) }\end{array}$ & $\begin{array}{c}\text { Improving } \\
\text { germination process } \\
\text { and salinity } \\
\text { tolerance, and } \\
\text { enhancing } \\
\text { chlorophyll content }\end{array}$ & [83] \\
\hline C. vulgaris & Biomass & Oryza sp. & $\begin{array}{l}\text { Improving } \\
\text { biological activity } \\
\text { and chemical } \\
\text { properties of the soil } \\
\text { and increasing the } \\
\text { availability of } \\
\text { macronutrients }\end{array}$ & [77] \\
\hline $\begin{array}{c}\text { Microalgal } \\
\text { bacterial flocs }\end{array}$ & Biomass & $\begin{array}{c}\text { Solanum } \\
\text { lycopersicum }\end{array}$ & $\begin{array}{l}\text { Improving fruit } \\
\text { quality through an } \\
\text { increase in sugar } \\
\text { and carotenoid } \\
\text { content }\end{array}$ & [78] \\
\hline $\begin{array}{l}\text { Nannochloropsis } \\
\text { sp. }\end{array}$ & Biomass & $\begin{array}{c}\text { Solanum } \\
\text { lycopersicum }\end{array}$ & $\begin{array}{l}\text { Improving fruit } \\
\text { quality through an } \\
\text { increase in sugar } \\
\text { and carotenoid } \\
\text { content }\end{array}$ & [78] \\
\hline S. platensis & Biomass & Eruca sativa & $\begin{array}{l}\text { Enhancing plant } \\
\text { growth and } \\
\text { improving } \\
\text { germination process }\end{array}$ & [82] \\
\hline S. platensis & Biomass & $\begin{array}{l}\text { Amaranthus } \\
\text { gangeticus }\end{array}$ & $\begin{array}{l}\text { Enhancing plant } \\
\text { growth and } \\
\text { improving } \\
\text { germination process }\end{array}$ & [82] \\
\hline S. platensis & Biomass & $\begin{array}{l}\text { Brassica rapa spp. } \\
\text { chinensis }\end{array}$ & $\begin{array}{l}\text { Enhancing plant } \\
\text { growth and } \\
\text { improving } \\
\text { germination process }\end{array}$ & [82] \\
\hline S. platensis & Biomass & $\begin{array}{l}\text { Brassica oleracea } \\
\text { alboglabra }\end{array}$ & $\begin{array}{l}\text { Enhancing plant } \\
\text { growth and } \\
\text { improving } \\
\text { germination process }\end{array}$ & [82] \\
\hline S. platensis & Biomass & Oryza sp. & $\begin{array}{l}\text { Improving } \\
\text { biological activity } \\
\text { and chemical } \\
\text { properties of the soil } \\
\text { and increasing the } \\
\text { availability of } \\
\text { macronutrients }\end{array}$ & [77] \\
\hline
\end{tabular}




\subsection{Biopesticides}

The implementation of biopesticides in agriculture is an important goal for the development of sustainable agriculture practices [84]. Pesticides of biological origin can act efficiently in pest control through a variety of mechanisms, such as by inhibiting the growth, nutrition, development, or reproduction of pests or pathogens [85].

In relation to the production of biopesticides, microalgae and cyanobacteria may be considered as potential biocontrol agents: they exhibit antagonistic effects against many plant pathogens, e.g., bacteria and fungi, mainly as a result of production of hydrolytic enzymes and biocidal compounds such as benzoic acid, majusculonic acid, etc. [86-89]. Therefore, the addition of microalgae in plant crops may stimulate the response to pathogens through different metabolic processes of plants, such as the activation of enzymes with defense function $[86,90]$.

With regard to the effects of cyanobacteria and microalgae on plant defense mechanisms, many studies have reported their ability to elucidate the antioxidant and pathogenesisrelated machinery of the plant [90]. For instance, Babu et al. [91] studied the effects of the inoculation with different cyanobacteria (Anabaena laxa RPAN8 and Calothrix sp.) on the activity of plant defense enzymes in wheat plant. Highest activity of peroxidase, polyphenol oxidase, and phenylalanine ammonia lyase was obtained in the treatments inoculated with Calothrix sp.

Therefore, plant-microalgae/cyanobacteria interactions may contribute to improve plant tolerance to different stress conditions [90]. The efficient use of these microorganisms as biochemicals for the control of plant diseases is often associated with the production of biocidal metabolites, which can suppress or kill pathogenic bacteria, fungi, or nematodes [92].

Specifically, the use of cyanobacteria has been associated with biocontrol by increasing the defense mechanisms in plants because it tends to stimulate the production and the action of antioxidant compounds [90]; while the microalgae can improve pest resistance, exerting nematocidal activity, antimicrobial activity against pathogenic bacteria and fungi, and insecticidal activity. Moreover, microalgae can produce allelochemicals for weed control [93].

In literature, many studies are available on the antifungal activity of microalgae. Scaglioni et al. [94] evaluated the ability of microalgae (Spirulina sp. and Nannochloropsis sp.) extracts to inhibit trichothecene production by Fusarium genus. The authors conducted the experiment in vitro in Petri dishes, containing potato dextrose agar (PDA) or PDA and whole grains, and performed different treatments: they evaluated the phenolic extract from each microalga at the concentration of $40 \mu \mathrm{g} \mathrm{mL}^{-1}$, compared to a control, cultured with only sterile water, and a treatment with the fungicide tebuconazole $\left(0.6 \mathrm{mg} \mathrm{mL}^{-1}\right)$. Each Petri dish was inoculated with an isolate of Fusarium. The results showed that both microalgae extracts have the capacity to inhibit the halo of fungal development in the substrate PDA or wheat grain, but they were less efficient compared to tebuconazole. However, with regard to the production of trichothecenes, the treatments with the phenolic extracts of Spirulina sp. and Nannochloropsis sp. were more efficient than the fungicide.

Ranglovà et al. [95] analyzed biopesticide effects of the extracts of $C$. vulgaris MACC-1, growth in two nutrient sources (BG-11 and municipal wastewater), using various bioassays, such as determination of inhibition index. The biopesticide activity of the extracts was tested against two fungi (Fusarium oxysporum f.sp melonis and Rhizoctonia solani), two oomycetes (Phytophthora capsici and Phytium ultimum), and four bacteria strains (Clavibacter michiganensis subsp. michiganensis, Xanthomonas campestris pv. vesicatoria, Pseudomonas syringae pv. tomato, and Pectobacterium carotovorum). The results showed that the antibacterial and antifungal activity were higher when $C$. vulgaris cultures were grown in urban wastewater as compared to those grown in BG-11; this could be associated with an accumulation of bioactive compounds responsible for antibacterial and even more for antifungal activity.

In Table 5 are summarized the microalgae species retrieved from recent literature, used as living cells or extracts, showing a plant biopesticides effect. 
Table 5. Biopesticide effects of different microalgae species.

\begin{tabular}{|c|c|c|c|c|}
\hline $\begin{array}{l}\text { Microalgae } \\
\text { Species }\end{array}$ & Application & $\begin{array}{c}\text { Microorganism } \\
\text { Target }\end{array}$ & Effects & Reference \\
\hline $\begin{array}{c}\text { Anabaena laxa } \\
\text { RPAN8 }\end{array}$ & $\begin{array}{c}\text { In vivo on } \\
\text { Gossypium } \\
\text { hirsutum F1861 } \\
\text { and Gossypium } \\
\text { arboretum CISA } \\
310\end{array}$ & Rhizoctonia spp. & $\begin{array}{l}\text { Enhancing the levels } \\
\text { of defense enzyme } \\
\text { activities, reducing } \\
\text { mortality, and } \\
\text { improving growth } \\
\text { and yield }\end{array}$ & [91] \\
\hline $\begin{array}{c}\text { C. vulgaris } \\
\text { MACC-1 } \\
\text { (cultivated in } \\
\text { BG-11) }\end{array}$ & In vitro & $\begin{array}{c}\text { Fusarium } \\
\text { oxysporum f.sp. } \\
\text { melonis }\end{array}$ & $\begin{array}{c}\text { Inhibiting } \\
\text { microorganism } \\
\text { development }\end{array}$ & [95] \\
\hline $\begin{array}{c}\text { C. vulgaris } \\
\text { MACC-1 } \\
\text { (cultivated in } \\
\text { BG-11) }\end{array}$ & In vitro & Rhizoctonia solani & $\begin{array}{l}\text { Inhibiting } \\
\text { microorganism } \\
\text { development }\end{array}$ & [95] \\
\hline $\begin{array}{c}\text { C. vulgaris } \\
\text { MACC-1 } \\
\text { (cultivated in } \\
\text { BG-11) }\end{array}$ & In vitro & $\begin{array}{l}\text { Phytophthora } \\
\text { capsici }\end{array}$ & $\begin{array}{l}\text { Inhibiting } \\
\text { microorganism } \\
\text { development }\end{array}$ & [95] \\
\hline $\begin{array}{c}\text { C. vulgaris } \\
\text { MACC-1 } \\
\text { (cultivated in } \\
\text { BG-11) }\end{array}$ & In vitro & $\begin{array}{l}\text { Clavibacter } \\
\text { michiganensis } \\
\text { subsp. } \\
\text { michiganensis }\end{array}$ & $\begin{array}{l}\text { Inhibiting } \\
\text { microorganism } \\
\text { development }\end{array}$ & [95] \\
\hline $\begin{array}{c}\text { C. vulgaris } \\
\text { MACC-1 } \\
\text { (cultivated } \\
\text { in urban } \\
\text { wastewater) }\end{array}$ & In vitro & $\begin{array}{c}\text { Fusarium } \\
\text { oxysporum f.sp. } \\
\text { melonis }\end{array}$ & $\begin{array}{l}\text { Inhibiting } \\
\text { microorganism } \\
\text { development }\end{array}$ & [95] \\
\hline $\begin{array}{l}\text { C. vulgaris } \\
\text { MACC-1 } \\
\text { (cultivated } \\
\text { in urban } \\
\text { wastewater) }\end{array}$ & In vitro & Rhizoctonia solani & $\begin{array}{l}\text { Inhibiting } \\
\text { microorganism } \\
\text { development }\end{array}$ & [95] \\
\hline $\begin{array}{l}\text { C. vulgaris } \\
\text { MACC-1 } \\
\text { (cultivated } \\
\text { in urban } \\
\text { wastewater) }\end{array}$ & In vitro & $\begin{array}{l}\text { Phytophthora } \\
\text { capsici }\end{array}$ & $\begin{array}{l}\text { Inhibiting } \\
\text { microorganism } \\
\text { development }\end{array}$ & [95] \\
\hline $\begin{array}{l}\text { C. vulgaris } \\
\text { MACC-1 } \\
\text { (cultivated } \\
\text { in urban } \\
\text { wastewater) }\end{array}$ & In vitro & Phytium ultimum & $\begin{array}{l}\text { Inhibiting } \\
\text { microorganism } \\
\text { development }\end{array}$ & [95] \\
\hline $\begin{array}{l}\text { C. vulgaris } \\
\text { MACC-1 } \\
\text { (cultivated } \\
\text { in urban } \\
\text { wastewater) }\end{array}$ & In vitro & $\begin{array}{l}\text { Clavibacter } \\
\text { michiganensis } \\
\text { subsp. } \\
\text { michiganensis }\end{array}$ & $\begin{array}{l}\text { Inhibiting } \\
\text { microorganism } \\
\text { development }\end{array}$ & [95] \\
\hline $\begin{array}{c}\text { C. vulgaris } \\
\text { MACC-1 } \\
\text { (cultivated } \\
\text { in urban } \\
\text { wastewater) }\end{array}$ & In vitro & $\begin{array}{c}\text { Xanthomonas } \\
\text { campestris pv. } \\
\text { vesicatoria }\end{array}$ & $\begin{array}{l}\text { Inhibiting } \\
\text { microorganism } \\
\text { development }\end{array}$ & [95] \\
\hline
\end{tabular}


Table 5. Cont.

\begin{tabular}{|c|c|c|c|c|}
\hline $\begin{array}{l}\text { Microalgae } \\
\text { Species }\end{array}$ & Application & $\begin{array}{c}\text { Microorganism } \\
\text { Target }\end{array}$ & Effects & Reference \\
\hline $\begin{array}{c}\text { C. vulgaris } \\
\text { MACC-1 } \\
\text { (cultivated } \\
\text { in urban } \\
\text { wastewater) }\end{array}$ & In vitro & $\begin{array}{l}\text { Pseudomonas } \\
\text { syringae pv. } \\
\text { tomato }\end{array}$ & $\begin{array}{c}\text { Inhibiting } \\
\text { microorganism } \\
\text { development }\end{array}$ & [95] \\
\hline $\begin{array}{c}\text { C. vulgaris } \\
\text { MACC-1 } \\
\text { (cultivated } \\
\text { in urban } \\
\text { wastewater) }\end{array}$ & In vitro & $\begin{array}{l}\text { Pectobacterium } \\
\text { carotovorum }\end{array}$ & $\begin{array}{c}\text { Inhibiting } \\
\text { microorganism } \\
\text { development }\end{array}$ & [95] \\
\hline Calothrix sp. & $\begin{array}{l}\text { In vivo on } \\
\text { Gossypium } \\
\text { hirsutum } \mathrm{F} 1861 \\
\text { and Gossypium } \\
\text { arboretum CISA } \\
\quad 310\end{array}$ & Rhizoctonia spp. & $\begin{array}{l}\text { Enhancing the levels } \\
\text { of defense enzyme } \\
\text { activities, reducing } \\
\text { mortality, and } \\
\text { improving growth } \\
\text { and yield }\end{array}$ & [91] \\
\hline Nannochloropsis sp. & In vitro & $\begin{array}{c}\text { Fusarium } \\
\text { graminearum } \\
\text { species complex }\end{array}$ & $\begin{array}{l}\text { Reducing mycelial } \\
\text { halo formation and } \\
\text { ergosterol } \\
\text { production, } \\
\text { inhibiting the } \\
\text { production of the } \\
\text { acetylates and the } \\
\text { production of } \\
\text { trichothecenes }\end{array}$ & [94] \\
\hline Spirulina sp. & In vitro & $\begin{array}{c}\text { Fusarium } \\
\text { graminearum } \\
\text { species complex }\end{array}$ & $\begin{array}{l}\text { Reducing mycelial } \\
\text { halo formation and } \\
\text { ergosterol } \\
\text { production, } \\
\text { inhibiting the } \\
\text { production of the } \\
\text { acetylates and the } \\
\text { production of } \\
\text { trichothecenes }\end{array}$ & [94] \\
\hline
\end{tabular}

\section{Future Perspective}

The multifunctionality of microalgae may offer an interesting perspective for the development of new technologies to remediate wastewater, due to their ability to remove organic and inorganic pollutants, meanwhile reducing the costs of production of microalgae biomasses, making the use of microalgae for treating wastewater possible, and reusing the residual biomasses for multipurpose agricultural applications. As a consequence of what is reported in the present review, a proposal for the future perspective may be summarized in Figure 4 . The hypothesis to use phycoremediation as secondary or tertiary treatment for wastewater treatment, and the reuse of the produced microalgae biomass, should be confirmed by (i) selection of the microalgae species which guarantee the best depuration efficiency for typology of wastewaters; (ii) microalgae growth in the selected wastewater; (iii) collection of microalgae biomasses at their stationary phase, and separation from water. After these steps, the depurated water and previously performed analysis which confirms the agronomic suitability may be used for irrigation, whereas microalgae biomass may be further processed to obtain products with different characteristics which can define the best agricultural application. An aliquot of the living microalgae biomass may be used to inoculate wastewater again which needs to be depurated by the phycoremediation system. 
This results in environmental and agriculture applications of microalgae, in accordance with an urgent worldwide request for an eco-sustainable agriculture.

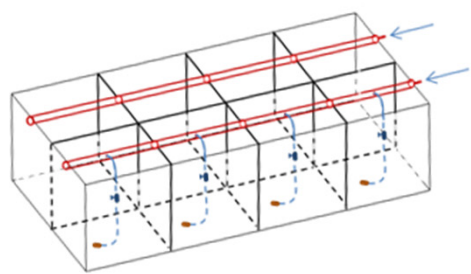

\section{Cultivation of microalgae}

1

Inoculum on urban and/or agricultural wastewater

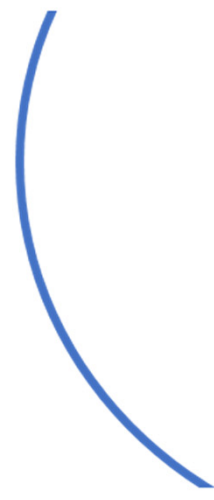

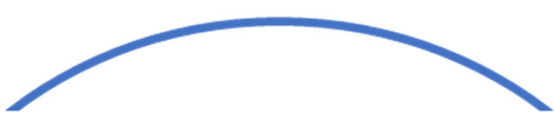

Phycoremediation process

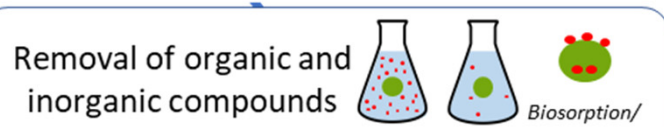
Bioaccumulation
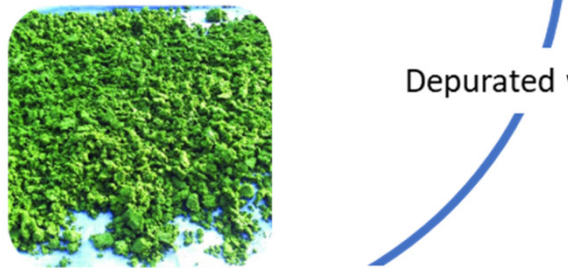

Depurated water
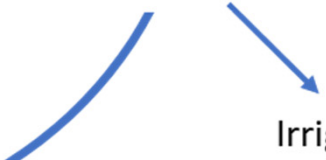

\section{Irrigation use}

Production and collecting of microalgal biomasses<smiles>C=CC</smiles>

Characterization of microalgae and their extracts
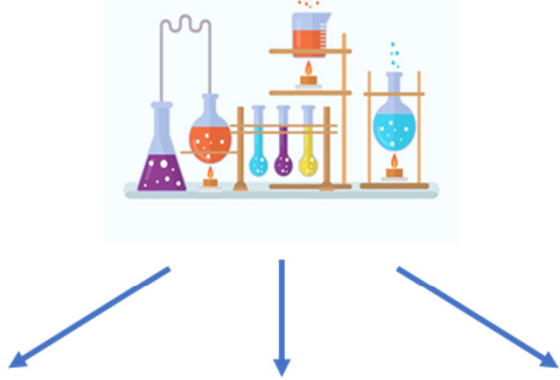

Biostimulant effects

Biofertilizer effects

Pesticide effects
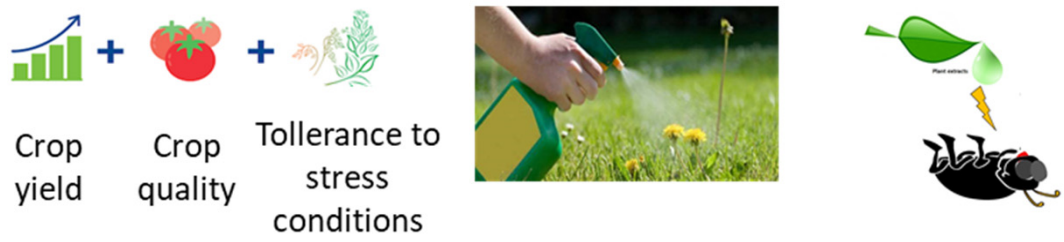

Figure 4. Ideal multipurpose applications of microalgae used for waste water treatment. 


\begin{abstract}
Author Contributions: Conceptualization, E.L.B.; methodology, E.L.B.; software, F.F.; validation, I.P. and A.B.; formal analysis, E.L.B.; investigation, E.L.B., I.P. and A.B.; resources, A.B.; data curation, E.L.B., I.P. and A.B.; writing-original draft preparation, E.L.B.; writing—review and editing, I.P. and A.B.; visualization, E.L.B. and F.F.; supervision, A.B.; project administration, A.B. and I.P. All authors have read and agreed to the published version of the manuscript.
\end{abstract}

Funding: Authors thank the grants which supported this work: PON "RICERCA E INNOVAZIONE" 2014-2020, Azione II-Obiettivo Specifico 1b-Progetto “Miglioramento delle produzioni agroalimentari mediterranee in condizioni di carenza di risorse idriche-WATER4AGRIFOOD" and "STARTING GRANT 2020"-University of Catania (Italy).

Institutional Review Board Statement: Not applicable.

Informed Consent Statement: Not applicable.

Conflicts of Interest: The authors declare no conflict of interest.

\title{
References
}

1. Chai, W.S.; Tan, W.G.; Halimatul Munawaroh, H.S.; Gupta, V.K.; Ho, S.H.; Show, P.L. Multifaceted Roles of Microalgae in the Application of Wastewater Biotreatment: A Review. Environ. Pollut. 2021, 269, 116236. [CrossRef]

2. Wollmann, F.; Dietze, S.; Ackermann, J.U.; Bley, T.; Walther, T.; Steingroewer, J.; Krujatz, F. Microalgae Wastewater Treatment: Biological and Technological Approaches. Eng. Life Sci. 2019, 19, 860-871. [CrossRef] [PubMed]

3. Bolognesi, S.; Bernardi, G.; Callegari, A.; Dondi, D.; Capodaglio, A.G. Biochar Production from Sewage Sludge and Microalgae Mixtures: Properties, Sustainability and Possible Role in Circular Economy. Biomass Convers. Biorefinery 2021, 11, 289-299. [CrossRef]

4. Rizzo, L.; Malato, S.; Antakyali, D.; Beretsou, V.G.; Đolić, M.B.; Gernjak, W.; Heath, E.; Ivancev-Tumbas, I.; Karaolia, P.; Lado Ribeiro, A.R.; et al. Consolidated vs New Advanced Treatment Methods for the Removal of Contaminants of Emerging Concern from Urban Wastewater. Sci. Total Environ. 2019, 655, 986-1008. [CrossRef] [PubMed]

5. Puzowski, P.; Skoczko, I. Investigation on Magnetic Field Usage for Urban Water Treatment. Proceedings 2020, 51, 1031. [CrossRef]

6. Skoczko, I.; Puzowski, P.; Szatyłowicz, E. Experience from the Implementation and Operation of the Biological Membrane Reactor (Mbr) at the Modernized Wastewater Treatment Plant in Wydminyt. Water 2020, 12, 3410. [CrossRef]

7. Crini, G.; Lichtfouse, E. Advantages and Disadvantages of Techniques Used for Wastewater Treatment. Environ. Chem. Lett. 2019, 17, 145-155. [CrossRef]

8. Sonune, A.; Ghate, R. Developments in Wastewater Treatment Methods. Desalination 2004, 167, 55-63. [CrossRef]

9. Zinicovscaia, I. Conventional Methods of Wastewater Treatment. In Cyanobacteria for Bioremediation of Wastewaters; Springer: Berlin/Heidelberg, Germany, 2016; pp. 17-25. ISBN 9783319267517.

10. Sharma, S.; Singh, B.; Manchanda, V.K. Phytoremediation: Role of Terrestrial Plants and Aquatic Macrophytes in the Remediation of Radionuclides and Heavy Metal Contaminated Soil and Water. Environ. Sci. Pollut. Res. 2015, 22, 946-962. [CrossRef]

11. Dar, S.H.; Kumawat, D.M.; Singh, N.; Wani, K.A. Sewage Treatment Potential of Water Hyacinth (Eichhornia Crassipes). Res. J. Environ. Sci. 2011, 5, 377. [CrossRef]

12. Rahman, M.A.; Hasegawa, H. Aquatic Arsenic: Phytoremediation Using Floating Macrophytes. Chemosphere 2011, 83, 633-646. [CrossRef]

13. Malaviya, P.; Singh, A. Constructed Wetlands for Management of Urban Stormwater Runoff. Crit. Rev. Environ. Sci. Technol. 2012, 42, 2153-2214. [CrossRef]

14. Zhang, D.; Gersberg, R.M.; Ng, W.J.; Tan, S.K. Removal of Pharmaceuticals and Personal Care Products in Aquatic Plant-Based Systems: A Review. Environ. Pollut. 2014, 184, 620-639. [CrossRef]

15. Ahmad, J.; Abdullah, S.R.S.; Hassan, H.A.; Rahman, R.A.A.; Idris, M. Saringan Tumbuhan Akuatik Tropika Tempatan Untuk Rawatan Penyudahan Sisa Pulpa Dan Kertas. Malays. J. Anal. Sci. 2017, 21, 105-112. [CrossRef]

16. Luo, L.; He, H.; Yang, C.; Wen, S.; Zeng, G.; Wu, M.; Zhou, Z.; Lou, W. Nutrient Removal and Lipid Production by Coelastrella Sp. in Anaerobically and Aerobically Treated Swine Wastewater. Bioresour. Technol. 2016, 216, 135-141. [CrossRef] [PubMed]

17. Abdel-Raouf, N.; Al-Homaidan, A.A.; Ibraheem, I.B.M. Microalgae and Wastewater Treatment. Saudi J. Biol. Sci. 2012, 19, 257-275. [CrossRef] [PubMed]

18. Chen, X.; Zhang, C.; Tan, L.; Wang, J. Toxicity of Co Nanoparticles on Three Species of Marine Microalgae. Environ. Pollut. 2018, 236, 454-461. [CrossRef] [PubMed]

19. Koppel, D.J.; Adams, M.S.; King, C.K.; Jolley, D.F. Chronic Toxicity of an Environmentally Relevant and Equitoxic Ratio of Five Metals to Two Antarctic Marine Microalgae Shows Complex Mixture Interactivity. Environ. Pollut. 2018, 242, 1319-1330. [CrossRef] [PubMed]

20. Li, M.; Xiao, X.; Wang, S.; Zhang, X.; Li, J.; Pavlostathis, S.G.; Luo, X.; Luo, S.; Zeng, G. Synergistic Removal of Cadmium and Organic Matter by a Microalgae-Endophyte Symbiotic System (MESS): An Approach to Improve the Application Potential of Plant-Derived Biosorbents. Environ. Pollut. 2020, 261, 114177. [CrossRef] 
21. Suganya, T.; Varman, M.; Masjuki, H.H.; Renganathan, S. Macroalgae and Microalgae as a Potential Source for Commercial Applications along with Biofuels Production: A Biorefinery Approach. Renew. Sustain. Energy Rev. 2016, 55, 909-941. [CrossRef]

22. Quijano, G.; Arcila, J.S.; Buitrón, G. Microalgal-Bacterial Aggregates: Applications and Perspectives for Wastewater Treatment. Biotechnol. Adv. 2017, 35, 772-781. [CrossRef] [PubMed]

23. Rawat, I.; Ranjith Kumar, R.; Mutanda, T.; Bux, F. Dual Role of Microalgae: Phycoremediation of Domestic Wastewater and Biomass Production for Sustainable Biofuels Production. Appl. Energy 2011, 88, 3411-3424. [CrossRef]

24. Zhu, Y.; Tu, X.; Chai, X.S.; Wei, Q.; Guo, L. Biological Activities and Nitrogen and Phosphorus Removal during the Anabaena Flos-Aquae Biofilm Growth Using Different Nutrient Form. Bioresour. Technol. 2018, 251, 7-12. [CrossRef]

25. Hena, S.; Znad, H.; Heong, K.T.; Judd, S. Dairy Farm Wastewater Treatment and Lipid Accumulation by Arthrospira Platensis. Water Res. 2018, 128, 267-277. [CrossRef]

26. Renuka, N.; Sood, A.; Ratha, S.K.; Prasanna, R.; Ahluwalia, A.S. nutrient sequestration, biomass production by microalgae and phytoremediation of sewage water. Int. J. Phytoremediation 2013, 15, 789-800. [CrossRef]

27. Rasoul-Amini, S.; Montazeri-Najafabady, N.; Shaker, S.; Safari, A.; Kazemi, A.; Mousavi, P.; Mobasher, M.A.; Ghasemi, Y. Removal of Nitrogen and Phosphorus from Wastewater Using Microalgae Free Cells in Bath Culture System. Biocatal. Agric. Biotechnol. 2014, 3, 126-131. [CrossRef]

28. Colak, O.; Kaya, Z. A Study on the Possibilities of Biological Wastewater Treatment Using Algae. Doga. Biyoloji. Serisi. 1988, 12, 18-29.

29. Wang, L.; Min, M.; Li, Y.; Chen, P.; Chen, Y.; Liu, Y.; Wang, Y.; Ruan, R. Cultivation of Green Algae Chlorella Sp. in Different Wastewaters from Municipal Wastewater Treatment Plant. Appl. Biochem. Biotechnol. 2010, 162, 1174-1186. [CrossRef]

30. Lau, P.S.; Tam, N.F.Y.; Wong, Y.S. Wastewater Nutrients Removal by Chlorella Vulgaris: Optimization Through Acclimation. Environ. Technol. 1996, 17, 183-189. [CrossRef]

31. Baglieri, A.; Sidella, S.; Barone, V.; Fragalà, F.; Silkina, A.; Nègre, M.; Gennari, M. Cultivating Chlorella Vulgaris and Scenedesmus Quadricauda Microalgae to Degrade Inorganic Compounds and Pesticides in Water. Environ. Sci. Pollut. Res. 2016, 23, 18165-18174. [CrossRef]

32. Martinez, M.E.; Sanchez, S.; Jimenez, J.M.; el Yousfi, F.; Munoz, L. Nitrogen and Phosphorus Removal from Urban Wastewater by the Microalga Scenedesmus Obliquus. Bioresour. Technol. 2000, 73, 263-272. [CrossRef]

33. Xin, L.; Hong-ying, H.; Jia, Y. Lipid Accumulation and Nutrient Removal Properties of a Newly Isolated Freshwater Microalga, Scenedesmus Sp. LX1, Growing in Secondary Effluent. New Biotechnol. 2010, 27, 59-63. [CrossRef] [PubMed]

34. Baglieri, A.; Reyneri, A.; Gennari, M.; Nègre, M. Organically Modified Clays as Binders of Fumonisins in Feedstocks. J. Environ. Sci. Health Part B 2013, 48, 776-783. [CrossRef] [PubMed]

35. Lananan, F.; Mohd Yunos, F.H.; Mohd Nasir, N.; Abu Bakar, N.S.; Lam, S.S.; Jusoh, A. Optimization of Biomass Harvesting of Microalgae, Chlorella Sp. Utilizing Auto-Flocculating Microalgae, Ankistrodesmus Sp. as Bio-Flocculant. Int. Biodeterior. Biodegrad. 2016, 113, 391-396. [CrossRef]

36. Ruiz-Marin, A.; Mendoza-Espinosa, L.G.; Stephenson, T. Growth and Nutrient Removal in Free and Immobilized Green Algae in Batch and Semi-Continuous Cultures Treating Real Wastewater. Bioresour. Technol. 2010, 101, 58-64. [CrossRef] [PubMed]

37. Zhang, E.; Wang, B.; Wang, Q.; Zhang, S.; Zhao, B. Ammonia-Nitrogen and Orthophosphate Removal by Immobilized Scenedesmus Sp. Isolated from Municipal Wastewater for Potential Use in Tertiary Treatment. Bioresour. Technol. 2008, 99, 3787-3793. [CrossRef]

38. Kurade, M.B.; Kim, J.R.; Govindwar, S.P.; Jeon, B.H. Insights into Microalgae Mediated Biodegradation of Diazinon by Chlorella Vulgaris: Microalgal Tolerance to Xenobiotic Pollutants and Metabolism. Algal Res. 2016, 20, 126-134. [CrossRef]

39. Tilman, D.; Cassman, K.G.; Matson, P.A.; Naylor, R.; Polasky, S. Agricultural sustainability and Intensive Production Practices. Nature 2002, 418, 671-677. [CrossRef]

40. Puglisi, I.; Nicolosi, E.; Vanella, D.; lo Piero, A.R.; Stagno, F.; Saitta, D.; Roccuzzo, G.; Consoli, S.; Baglieri, A. Physiological and Biochemical Responses of Orange Trees to Different Deficit Irrigation Regimes. Plants 2019, 8, 423. [CrossRef]

41. Yakhin, O.I.; Lubyanov, A.A.; Yakhin, I.A.; Brown, P.H. Biostimulants in Plant Science: A Global Perspective. Front. Plant Sci. 2017, 7, 2049. [CrossRef]

42. Kocira, A.; Świeca, M.; Kocira, S.; Złotek, U.; Jakubczyk, A. Enhancement of Yield, Nutritional and Nutraceutical Properties of Two Common Bean Cultivars Following the Application of Seaweed Extract (Ecklonia Maxima). Saudi J. Biol. Sci. 2018, 25, 563-571. [CrossRef]

43. du Jardin, P. Plant Biostimulants: Definition, Concept, Main Categories and Regulation. Sci. Hortic. 2015, 196, 3-14. [CrossRef]

44. Hultberg, M.; Carlsson, A.S.; Gustafsson, S. Treatment of Drainage Solution from Hydroponic Greenhouse Production with Microalgae. Bioresour. Technol. 2013, 136, 401-406. [CrossRef]

45. Mata, T.M.; Martins, A.A.; Caetano, N.S. Microalgae for Biodiesel Production and Other Applications: A Review. Renew. Sustain. Energy Rev. 2010, 14, 217-232. [CrossRef]

46. Gong, Y.; Jiang, M. Biodiesel Production with Microalgae as Feedstock: From Strains to Biodiesel. Biotechnol. Lett. 2011, 33, 1269-1284. [CrossRef] [PubMed]

47. Barone, V.; Puglisi, I.; Fragalà, F.; lo Piero, A.R.; Giuffrida, F.; Baglieri, A. Novel Bioprocess for the Cultivation of Microalgae in Hydroponic Growing System of Tomato Plants. J. Appl. Phycol. 2019, 31, 465-470. [CrossRef] 
48. Puglisi, I.; Barone, V.; Sidella, S.; Coppa, M.; Broccanello, C.; Gennari, M.; Baglieri, A. Biostimulant Activity of Humic-like Substances from Agro-Industrial Waste on Chlorella Vulgaris and Scenedesmus Quadricauda. Eur. J. Phycol. 2018, 53, 433-442. [CrossRef]

49. Zhang, J.; Wang, X.; Zhou, Q. Co-Cultivation of Chlorella Spp and Tomato in a Hydroponic System. Biomass Bioenergy 2017, 97, 132-138. [CrossRef]

50. Gonçalves, A.L. The Use of Microalgae and Cyanobacteria in the Improvement of Agricultural Practices: A Review on Their Biofertilising, Biostimulating and Biopesticide Roles. Appl. Sci. 2021, 11, 871. [CrossRef]

51. Chiaiese, P.; Corrado, G.; Colla, G.; Kyriacou, M.C.; Rouphael, Y. Renewable Sources of Plant Biostimulation: Microalgae as a Sustainable Means to Improve Crop Performance. Front. Plant Sci. 2018, 9, 1782. [CrossRef] [PubMed]

52. Ronga, D.; Biazzi, E.; Parati, K.; Carminati, D.; Carminati, E.; Tava, A. Microalgal Biostimulants and Biofertilisers in Crop Productions. Agronomy 2019, 9, 192. [CrossRef]

53. Win, T.T.; Barone, G.D.; Secundo, F.; Fu, P. Algal Biofertilizers and Plant Growth Stimulants for Sustainable Agriculture. Ind. Biotechnol. 2018, 14, 203-211. [CrossRef]

54. Kusvuran, A.; Kusvuran, S. Using of Microbial Fertilizer as Biostimulant Alleviates Damage from Drought Stress in Guar (Cyamopsis Tetragonoloba (L.) Taub.) Seedlings. Int. Lett. Nat. Sci. 2019, 76, 147-157. [CrossRef]

55. Reddy, C.A.; Saravanan, R.S. Polymicrobial Multi-Functional Approach for Enhancement of Crop Productivity. In Advances in Applied Microbiology; Academic Press Inc.: London, UK, 2013; Volume 82, pp. 53-113.

56. Bulgari, R.; Cocetta, G.; Trivellini, A.; Vernieri, P.; Ferrante, A. Biostimulants and Crop Responses: A Review. Biol. Agric. Hortic. 2015, 31, 1-17. [CrossRef]

57. Parrado, J.; Bautista, J.; Romero, E.J.; García-Martínez, A.M.; Friaza, V.; Tejada, M. Production of a Carob Enzymatic Extract: Potential Use as a Biofertilizer. Bioresour. Technol. 2008, 99, 2312-2318. [CrossRef] [PubMed]

58. Ertani, A.; Pizzeghello, D.; Baglieri, A.; Cadili, V.; Tambone, F.; Gennari, M.; Nardi, S. Humic-like Substances from Agro-Industrial Residues Affect Growth and Nitrogen Assimilation in Maize (Zea Mays L.) Plantlets. J. Geochem. Explor. 2013, 129, $103-111$. [CrossRef]

59. Baglieri, A.; Cadili, V.; Mozzetti Monterumici, C.; Gennari, M.; Tabasso, S.; Montoneri, E.; Nardi, S.; Negre, M. Fertilization of Bean Plants with Tomato Plants Hydrolysates. Effect on Biomass Production, Chlorophyll Content and N Assimilation. Sci. Hortic. 2014, 176, 194-199. [CrossRef]

60. Alam, M.Z.; Braun, G.; Norrie, J.; Hodges, D.M. Ascophyllum Extract Application Can Promote Plant Growth and Root Yield in Carrot Associated with Increased Root-Zone Soil Microbial Activity. Can. J. Plant Sci. 2014, 94, 337-348. [CrossRef]

61. Rouphael, Y.; Giordano, M.; Cardarelli, M.; Cozzolino, E.; Mori, M.; Kyriacou, M.C.; Bonini, P.; Colla, G. Plant-and Seaweed-Based Extracts Increase Yield but Differentially Modulate Nutritional Quality of Greenhouse Spinach through Biostimulant Action. Agronomy 2018, 8, 126. [CrossRef]

62. Colla, G.; Nardi, S.; Cardarelli, M.; Ertani, A.; Lucini, L.; Canaguier, R.; Rouphael, Y. Protein Hydrolysates as Biostimulants in Horticulture. Sci. Hortic. 2015, 196, 28-38. [CrossRef]

63. Battacharyya, D.; Babgohari, M.Z.; Rathor, P.; Prithiviraj, B. Seaweed Extracts as Biostimulants in Horticulture. Sci. Hortic. 2015, 196, 39-48. [CrossRef]

64. Stirk, W.A.; Ördög, V.; Novák, O.; Rolčík, J.; Strnad, M.; Bálint, P.; van Staden, J. Auxin and Cytokinin Relationships in 24 Microalgal Strains1. J. Phycol. 2013, 49, 459-467. [CrossRef]

65. Tate, J.J.; Gutierrez-Wing, M.T.; Rusch, K.A.; Benton, M.G. The Effects of Plant Growth Substances and Mixed Cultures on Growth and Metabolite Production of Green Algae Chlorella Sp.: A Review. J. Plant Growth Regul. 2013, 32, 417-428. [CrossRef]

66. Spolaore, P.; Joannis-Cassan, C.; Duran, E.; Isambert, A. Commercial Applications of Microalgae. J. Biosci. Bioeng. 2006, 101, 87-96. [CrossRef]

67. Barone, V.; Baglieri, A.; Stevanato, P.; Broccanello, C.; Bertoldo, G.; Bertaggia, M.; Cagnin, M.; Pizzeghello, D.; Moliterni, V.M.C.; Mandolino, G.; et al. Root Morphological and Molecular Responses Induced by Microalgae Extracts in Sugar Beet (Beta Vulgaris L.). J. Appl. Phycol. 2018, 30, 1061-1071. [CrossRef]

68. Puglisi, I.; Barone, V.; Fragalà, F.; Stevanato, P.; Baglieri, A.; Vitale, A. Effect of Microalgal Extracts from Chlorella Vulgaris and Scenedesmus Quadricauda on Germination of Beta Vulgaris Seeds. Plants 2020, 9, 675. [CrossRef]

69. Barone, V.; Puglisi, I.; Fragalà, F.; Stevanato, P.; Baglieri, A. Effect of Living Cells of Microalgae or Their Extracts on Soil Enzyme Activities. Arch. Agron. Soil Sci. 2019, 65, 712-726. [CrossRef]

70. Puglisi, I.; La Bella, E.; Rovetto, E.I.; lo Piero, A.R.; Baglieri, A. Biostimulant Effect and Biochemical Response in Lettuce Seedlings Treated with a Scenedesmus Quadricauda Extract. Plants 2020, 9, 123. [CrossRef] [PubMed]

71. La Bella, E.; Baglieri, A.; Rovetto, E.I.; Stevanato, P.; Puglisi, I. Foliar Spray Application of Chlorella Vulgaris Extract: Effect on the Growth of Lettuce Seedlings. Agronomy 2021, 11, 308. [CrossRef]

72. Puglisi, I.; La Bella, E.; Rovetto, E.I.; Stevanato, P.; Fascella, G.; Baglieri, A. Morpho-biometric and Biochemical Responses in Lettuce Seedlings Treated by Different Application Methods of Chlorella Vulgaris Extract: Foliar Spray or Root Drench? J. Appl. Phycol. 2021. [CrossRef]

73. Garcia-Gonzalez, J.; Sommerfeld, M. Biofertilizer and Biostimulant Properties of the Microalga Acutodesmus Dimorphus. J. Appl. Phycol. 2016, 28, 1051-1061. [CrossRef] [PubMed] 
74. Plaza, B.M.; Gómez-Serrano, C.; Acién-Fernández, F.G.; Jimenez-Becker, S. Effect of Microalgae Hydrolysate Foliar Application (Arthrospira Platensis and Scenedesmus Sp.) on Petunia x Hybrida Growth. J. Appl. Phycol. 2018, 30, 2359-2365. [CrossRef]

75. Mutale-joan, C.; Redouane, B.; Najib, E.; Yassine, K.; Lyamlouli, K.; Laila, S.; Zeroual, Y.; Hicham, E.A. Screening of Microalgae Liquid Extracts for Their Bio Stimulant Properties on Plant Growth, Nutrient Uptake and Metabolite Profile of Solanum Lycopersicum L. Sci. Rep. 2020, 10, 1-12. [CrossRef] [PubMed]

76. Chien, S.H.; Prochnow, L.I.; Cantarella, H. Chapter 8 Recent Developments of Fertilizer Production and Use to Improve Nutrient Efficiency and Minimize Environmental Impacts. Adv. Agron. 2009, 102, 267-322.

77. Dineshkumar, R.; Kumaravel, R.; Gopalsamy, J.; Sikder, M.N.A.; Sampathkumar, P. Microalgae as Bio-Fertilizers for Rice Growth and Seed Yield Productivity. Waste Biomass Valorization 2018, 9, 793-800. [CrossRef]

78. Coppens, J.; Grunert, O.; van den Hende, S.; Vanhoutte, I.; Boon, N.; Haesaert, G.; de Gelder, L. The Use of Microalgae as a High-Value Organic Slow-Release Fertilizer Results in Tomatoes with Increased Carotenoid and Sugar Levels. J. Appl. Phycol. 2016, 28, 2367-2377. [CrossRef]

79. Schreiber, C.; Schiedung, H.; Harrison, L.; Briese, C.; Ackermann, B.; Kant, J.; Schrey, S.D.; Hofmann, D.; Singh, D.; Ebenhöh, O.; et al. Evaluating Potential of Green Alga Chlorella Vulgaris to Accumulate Phosphorus and to Fertilize Nutrient-Poor Soil Substrates for Crop Plants. J. Appl. Phycol. 2018, 30, 2827-2836. [CrossRef]

80. Shaaban, M.M. Nutritional Status and Growth of Maize Plants as Affected by Green Microalgae as Soil Additives. J. Biol. Sci. 2001, 1, 475-479. [CrossRef]

81. Faheed, F.A.; Abdel Fattah, Z. Effect of Chlorella Vulgaris as Bio-Fertilizer on Growth Parameters and Metabolic Aspects of Lettuce Plant. J. Agric. Soc. Sci. 2008, 4, 165-169.

82. Wuang, S.C.; Khin, M.C.; Chua, P.Q.D.; Luo, Y.D. Use of Spirulina Biomass Produced from Treatment of Aquaculture Wastewater as Agricultural Fertilizers. Algal Res. 2016, 15, 59-64. [CrossRef]

83. Elhafiz, A.A.; Gaur, A.E.S.S.; Osman, N.H.M.; Lakshmi, T.R. Chlorella Vulgaris and Chlorella Pyrenoidosa Cells Appear to Be Promising Sustainable to Grow Rice, Lettuce, Cucumber and eggplant in the UAE Soils. Recent Res. Sci. Technol. 2015, 7, 14-21. [CrossRef]

84. Costa, J.A.V.; Freitas, B.C.B.; Cruz, C.G.; Silveira, J.; Morais, M.G. Potential of Microalgae as Biopesticides to Contribute to Sustainable Agriculture and Environmental Development. J. Environ. Sci. Health-Part B Pestic. Food Contam. Agric. Wastes 2019, 54, 366-375. [CrossRef]

85. Mnif, I.; Ghribi, D. Potential of Bacterial Derived Biopesticides in Pest Management. Crop Prot. 2015, 77, 52-64. [CrossRef]

86. Gupta, V.; Ratha, S.K.; Sood, A.; Chaudhary, V.; Prasanna, R. New Insights into the Biodiversity and Applications of Cyanobacteria (Blue-Green Algae)-Prospects and Challenges. Algal Res. 2013, 2, 79-97. [CrossRef]

87. Prasanna, R.; Nain, L.; Tripathi, R.; Gupta, V.; Chaudhary, V.; Middha, S.; Joshi, M.; Ancha, R.; Kaushik, B.D. Evaluation of Fungicidal Activity of Extracellular Filtrates of Cyanobacteria-Possible Role of Hydrolytic Enzymes. J. Basic Microbiol. 2008, 48, 186-194. [CrossRef]

88. Chaudhary, V.; Prasanna, R.; Nain, L.; Dubey, S.C.; Gupta, V.; Singh, R.; Jaggi, S.; Bhatnagar, A.K. Bioefficacy of Novel Cyanobacteria-Amended Formulations in Suppressing Damping off Disease in Tomato Seedlings. World J. Microbiol. Biotechnol. 2012, 28, 3301-3310. [CrossRef]

89. Chandel, S.T. Nematicidal Activity of the Cyanobacterium, Aulosira Fertilissima on the Hatch of Meloidogyne Triticoryzae and Meloidogyne Incognita. Arch. Phytopathol. Plant Prot. 2009, 42, 32-38. [CrossRef]

90. Renuka, N.; Guldhe, A.; Prasanna, R.; Singh, P.; Bux, F. Microalgae as Multi-Functional Options in Modern Agriculture: Current Trends, Prospects and Challenges. Biotechnol. Adv. 2018, 36, 1255-1273. [CrossRef]

91. Babu, S.; Bidyarani, N.; Chopra, P.; Monga, D.; Kumar, R.; Prasanna, R.; Kranthi, S.; Saxena, A.K. Evaluating Microbe-Plant Interactions and Varietal Differences for Enhancing Biocontrol Efficacy in Root Rot Disease Challenged Cotton Crop. Eur. J. Plant Pathol. 2015, 142, 345-362. [CrossRef]

92. Swain, S.S.; Paidesetty, S.K.; Padhy, R.N. Antibacterial, Antifungal and Antimycobacterial Compounds from Cyanobacteria Biomed. Pharmacother. 2017, 90, 760-776. [CrossRef]

93. El-Mougy, N.S.; Abdel-Kader, M.M. Effect of Commercial Cyanobacteria Products on the Growth and Antagonistic Ability of Some Bioagents under Laboratory Conditions. J. Pathog. 2013, 2013, 1-11. [CrossRef]

94. Scaglioni, P.T.; de Oliveira Garcia, S.; Badiale-Furlong, E. Inhibition of in Vitro Trichothecenes Production by Microalgae Phenolic Extracts. Food Res. Int. 2019, 124, 175-180. [CrossRef]

95. Ranglová, K.; Lakatos, G.E.; Câmara Manoel, J.A.; Grivalský, T.; Suárez Estrella, F.; Acién Fernández, F.G.; Molnár, Z.; Ördög, V.; Masojídek, J. Growth, Biostimulant and Biopesticide Activity of the MACC-1 Chlorella Strain Cultivated Outdoors in Inorganic Medium and Wastewater. Algal Res. 2021, 53, 102136. [CrossRef] 